\title{
LA MEMORIA DEL PASADO COMO MECANISMO DE AFIRMA- CIÓN EN EL CÍSTER FEMENINO CASTELLANO DURANTE LA BAJA EDAD MEDIA Y LA EDAD MODERNA: MATERIALIDAD Y DISCURSO ESCRITO
}

Ester Penas González

Universidad Complutense de Madrid

Resumen: Durante la Baja Edad Media y la Edad Moderna algunos monasterios del Císter femenino recurrieron a su etapa plenomedieval para legitimar su posición en momentos en los que su autoridad estaba siendo cuestionada por instituciones eclesiásticas y laicas, tratando de lograr una mayor cohesión interna sobre la base de su memoria. Estudiaremos esta realidad a través de los ejemplos de San Andrés de Arroyo, Santa María de Cañas, Santa María de Vileña y San Vicente de Segovia.

Palabras clave: Pasado, autoridad, historiografía, linaje monástico.

THE MEMORY OF THE PAST AS MECHANISM OF AUTHORITY IN THE CISTERCIAN CASTILIAN NUNNERIES DURING THE LATE MIDDLE AGES AND MODERN AGE: MATERIALITY AND WRITTEN DISCURSE

Abstract: During the Late Middle Ages and the Modern Age some Cistercian nunneries appealed to their Medieval period to legitimize their position when their authority was being questioned by ecclesiastical and secular institutions, so they could achieve greater internal cohesion arround their memory. We will study this fact through the examples of San Andrés de Arroyo, Santa María de Cañas, Santa María de Vileña and San Vicente de Segovia.

Keywords: Past, Authority, Historiography, Monastic Lineage.

\footnotetext{
* Entregado: 15/05/2018. Aceptación definitiva: 09/10/2018
} 


\section{INTRODUCCIÓN ${ }^{1}$}

En este trabajo expondremos cómo algunos monasterios del Císter femenino castellano recurrieron durante la Baja Edad Media y la Edad Moderna a la construcción de la memoria de su pasado plenomedieval para afirmar su posición institucional y reforzar su identidad $^{2}$. Estas comunidades, de larga trayectoria eclesiástica y temporal, hicieron uso de mecanismos ideológicos legitimadores en determinados momentos en los que su autoridad fue puesta en duda. Por ello, su estudio permitirá conocer cómo, a través de la concepción de su pasado, organizaban su presente. Como veremos, no se trata de un comportamiento exclusivo de las comunidades femeninas ni de la Orden Cisterciense, si bien su condición pudo dar lugar a determinadas situaciones que hicieron necesario emplear estas herramientas. Por otro lado, estudiar cómo concebían el pasado medieval desde la Edad Moderna permite comprender el deseo de continuidad que las monjas tenían, haciendo valer sus privilegios y afianzando sus ámbitos de acción, especialmente en una orden de origen plenomedieval que se enfrentó durante la Baja Edad Media y la Edad Moderna a grandes cambios internos que generaron visibles diferencias con respecto a épocas anteriores. Gracias a la información proporcionada por cuatro fuentes escritas, dos tradiciones orales relativas a su etapa fundacional ${ }^{3}$, y los epígrafes y emblemas heráldicos empleados como medios de propaganda visual ${ }^{4}$, analizaremos cómo algunas comunidades cistercienses femeninas gestionaron y transmitieron su memoria.

Debemos considerar el amplio debate historiográfico existente entre los conceptos de historia y memoria ${ }^{5}$, para lo que recurriremos a la definición integrada de Georges Martin,

\footnotetext{
${ }^{1}$ Este estudio es fruto de un conjunto de reflexiones dirigidas a comprender la personalidad de doña Mencía junto con la RMA. Ma del Carmen Gordaliza (O. Cist.), del monasterio de San Andrés de Arroyo, de quien son muchas de las aportaciones que ahora introducimos. Abreviaturas empleadas: AHN (Archivo Histórico Nacional); AHNob (Archivo Histórico de la Nobleza); AMHB (Archivo del Monasterio de las Huelgas de Burgos); AMSAR (Archivo del Monasterio de San Andrés de Arroyo); AMSV (Archivo del Monasterio de San Vicente el Real de Segovia); BNE (Biblioteca Nacional de España); O. Cist. (Ordo Cisterciensis); OCSO (Ordo Cisterciensis Strictioris Observantiae) RMA (Reverenda Madre Abadesa); UNED (Universidad Nacional de Educación a Distancia).

${ }^{2}$ Como obras generales, citamos los trabajos de Jara Fuente, J. A., Martin, G., Alfonso Antón, I. (coords.), Construir identidad en la Edad Media, Universidad de Castilla la Mancha, Cuenca, 2010; ANDONI FERnÁNDEZ DE LARREA Y RoJAS, J., y DÍAZ DE DURANA ORTIZ DE UBIERNA, J. R. (coords.), Memoria e Historia: utilización política en la Corona de Castilla al final de la Edad Media, Sílex, Madrid, 2010; GUIANCE, A., y UbIERnA, P. (eds.), Sociedad y Memoria en la Edad Media. Estudios en homenaje a Nilda Guglielmi, Instituto Multidisciplinario de Historia y Ciencias Humanas, Buenos Aires, 2005; LóPEZ OJEDA, E. (coord.), La memoria del poder, el poder de la memoria. XXVII Semana de Estudios Medievales, Nájera, del 25 al 29 de julio de 2016, Instituto de Estudios Riojanos, Logroño, 2017; COMPANY, C., GonZÁLEZ, A., Walde Moheno, L., Discursos y representaciones en la Edad Media: actas de las VI Jornadas Medievales, México, Universidad Nacional Autónoma de México, 1999.

${ }^{3}$ Muchos monasterios plenomedievales exaltaron su fundación vinculándose a héroes y santos para mantener la posición alcanzada. GARCíA TURZA, J., «Los monjes y la escritura de la memoria: identidad y poder en Castilla», en La memoria del poder, el poder de la memoria, XXVII Semana de Estudios Medievales, Nájera, del 25 al 29 de julio de 2016, LÓPEZ OJEDA, E. (coord.), Instituto de Estudios Riojanos, Logroño, 2017, pp. 123-162.

${ }^{4}$ DACOSTA, A., «El noble ante el espejo: el origen del linaje en la escritura nobiliaria ibérica», en La memoria del poder, el poder de la memoria, XXVII Semana de Estudios Medievales, Nájera, del 25 al 29 de julio de 2016, LÓPEZ OJEDA, E. (coord.), Instituto de Estudios Riojanos, Logroño, 2017, p. 255.

${ }^{5}$ Sobre el debate historia-memoria: MARTIN, G., «Pasados para el presente, presentes para el futuro. Poder y memoria histórica en el Occidente peninsular durante la Edad Media», en La memoria del poder, el poder
} 
quien ha apuntado que la memoria histórica es la «conciencia presente, fundada en un saber más o menos rico y articulado, que tuvieron los hombres de la Edad Media del pasado de sus colectivos», siendo una realidad «profusa y polimorfa» y tremendamente compleja cuando se enlaza con el concepto de poder ${ }^{6}$. Por su parte, Quintanilla y Carceller han resaltado que historia y memoria «dependen de un fundamento común: el pasado», y que «la memoria, con su necesaria elaboración de los recuerdos, trae el pasado al presente con objeto de explicar realidades», a modo de «opción narrativa con funciones especiales, tanto de carácter didáctico, como claramente propagandístico» ${ }^{7}$. Marta Philip considera que «historia y memoria son representaciones del pasado, la primera tiene como objetivo la exactitud de la representación, mientras que la segunda pretende ser verosímil, no intenta reconstruir el pasado, sino instaurarlo, fundarlo» ${ }^{8}$, llegando a convertirse en un «objeto de estudio de la historia» ${ }^{9} \mathrm{y}$, por su parte, Arsenio Dacosta ha señalado que

existe un problema epistemológico en la concepción del pasado en términos de historia y memoria, toda vez que la primera, como artefacto, está sujeta a constantes reelaboraciones y reinterpretaciones, y la segunda, la memoria, es imposible de deslindarla ontológicamente de la primera - y viceversa—, al menos en la Edad Media ciertamente, memoria e historia se materializaban de forma distinta, y debemos preguntarnos [...] si la forma de percibir el tiempo histórico en ambas es el mismo ${ }^{10}$.

de la memoria, XXVII Semana de Estudios Medievales, Nájera, del 25 al 29 de julio de 2016, LóPEZ OJEDA, E. (coord.), Instituto de Estudios Riojanos, Logroño, 2017, pp. 15-44; SANMARTín, I., «La memoria y la historia medievales como realidades indisociables», Cuadernos de Estudios Gallegos, LIX.125 (2012), pp. 259-272; PHILIP, M., «Memoria y poder: el rescate de un problema clásico. Una mirada desde la historia política», Cuaderno de Historia. Serie Economía y Sociedad, 8 (2006), pp. 89-103; MARIMÓn LlORCA, C., " "La memoria de omne deleznadera es": oralidad, textualidad y medios de transmisión en la Edad Media», Dicenda. Cuadernos de Filología Hispánica, 24 (2006), pp. 139-159; CARRUTHERS, M., The book of memory. A Study of Memory in Medieval Culture, Cambridge University Press, Cambridge, 1990; FRENK AlATORRE, M., «Vista, oído y memoria en el vocabulario de la lectura. Edad Media y Renacimiento», en Discursos y representaciones en la Edad Media: Actas de las VI Jornadas Medievales, GonZÁLEZ, A., Walde Moheno, L., y Company Company, C., México, 1999, pp. 13-31; Murcia Conesa, A., «Memoria histórica de la Edad Media e idea de tradición en Menéndez Pidal y Américo Castro», Res publica: revista de filosofía política, 17 (2007), pp. 309-328; SÁNCHEZ-PRIETO BORJA, P., «Tiempo y memoria en las fuentes documentales de la Edad Media», Cuadernos del CEMYR, 24 (2016), pp. 11-30; VERGARA CiordiA, J., «La memoria en las obras pedagógicas de la Baja Edad Media», Bordón, 64 (4) (2012), pp. 111-122.

${ }^{6}$ MARTIN, G., «Pasados...», p. 15. Además, como herramienta de poder, la memoria se ligaba a los grupos de élite para mantener su hegemonía mediante «recursos de memoria colectiva», en QUINTANILLA RASO, Ma C., y CARCEller Cerviño, M ${ }^{a}$ P., «La construcción de la memoria de las grandes casas nobles en la Corona de Castilla. El marquesado de Priego y el ducado de Alburquerque», en La conciencia de los antepasados. La construcción de la memoria de la nobleza en la Baja Edad Media, DACOSTA, A., PRIETO LASA, J. R., y DíAZ DE DuRANA, J. R. (eds.), Marcial Pons, Madrid, 2014, p. 272. Véase también NiETo SORIA, J. M., «Corona e identidad política en Castilla», en Construir la identidad en la Edad Media, JARA FUENTE, J. A., Martin, G., y Alfonso Antón, I. (coords.), Universidad de Castilla la Mancha, Cuenca, 2010, pp. 183-208.

${ }^{7}$ Quintanilla Raso, $\mathrm{M}^{a}$ C., y CARCEller Cerviño, Ma P., «La construcción...», p. 271.

${ }^{8}$ PHILIP, M., «Memoria...», p. 92.

${ }^{9}$ Ibidem, p. 96.

${ }^{10}$ DACOSTA, A., «El noble...», p. 289. 
Israel Sanmartín ha apuntado la «capacidad del presente para reelaborar las memorias y hacer presente lo ausente», de manera que historia y memoria estarían relacionadas y contenidas la segunda en la primera, en un momento en el que el presente estaba dotado de una enorme relevancia ${ }^{11}$. Jara Fuente vincula además el concepto de identidad al de memoria, puesto que ambos «se encuentran en la base de todo proceso de construcción [...] social, cualquiera que sea el nivel de escala en el que aquél tenga lugar» ${ }^{12}$, y añade que «memoria e identidad son procesos interrelacionados y comunicados [...] de posicionamiento del sujeto "yo" y del sujeto "otros" en un realidad compartida o vivida» 13 , que integra tres ejes principales: territorio, naturaleza y agencia, definidos por Julio Escalona ${ }^{14}$.

Siguiendo estos tres conceptos, nos vamos a referir a identidades monásticas, insertas en una escala microespacial en la que el Císter se vinculaba estrechamente a un lugar ${ }^{15}$ paisaje espiritual ${ }^{16}$ y vivencial- , en un contexto natural para encontrar a Dios en el alejamiento del caos mundano ${ }^{17}$, y con una identidad común de pertenencia a un grupo cuya esencia era seguir y buscar al Señor. Sin embargo, no solo los monasterios recurrieron a su memoria $^{18}$; también utilizaron esta herramienta las instituciones eclesiásticas seculares, la

${ }^{11}$ SANMARTín, I., «La memoria...», pp. 261-262.

${ }^{12}$ JARA FUENTE, J. A., «Introducción: memoria de una identidad (de identidades). Castilla en la Edad Media», en Construir la identidad en la Edad Media, JaRA Fuente, J. A., MARTin, G., y Alfonso ANTón, I. (coords.), Universidad de Castilla la Mancha, Cuenca, 2010, p. 10.

${ }^{13}$ Ibidem, p. 11.

${ }^{14}$ ESCALONA MONGE, J., «Territorialidad e identidades en la Castilla condal», en Construir la identidad en la Edad Media, JARA Fuente, J. A.; MARTin, G., y Alfonso ANTÓn, I. (coords.), Universidad de Castilla la Mancha, Cuenca, 2010, p. 56.

${ }^{15}$ SAn Benito, La Regla, y SAN GRegorio Magno, Libro II de los «Diálogos», traducción de ARANGUREN, I., y SANSEgundo, L. M., Biblioteca de Autores Cristianos, Madrid, ed. 2010, Prólogo, pp. 31-34, y Capítulo I, p. 34. Y las referencias: (1) «hemos creído preferible que os vayáis vosotros al lugar que os depare la divina Providencia y sirváis allí al Señor con mayor provecho y tranquilidad», Exordium Parvum, Capítulo II; (2) «A los hermanos que vinieron con él les hizo prometer estabilidad en el lugar según la Regla», Exordium Parvum, Capítulo IV. La traducción latina puede consultarse en GUIGNARD, P., Les monuments primitifs de la Règle cistercienne, Rabutot, Dijon, (1878), pp. 62-63.

${ }^{16}$ Concepto propuesto por CLAUSTRA: http://www.ub.edu/claustra/spa/info/acerca del proyecto claustra (consultado el 09/05/2018 a las 19:51); CoRBELLINI, S., «Mapping spiritual life: a spatial approach to late medieval spirituality», Anuario de Estudios Medievales, 44.1 (2014), pp. 81-100; GARí, B., «Presentación: oh dear, it's nuns! ¿Por qué hablar de espacios de espiritualidad femenina en la Edad Media?», Anuario de Estudios Medievales, 44.1 (2014), pp. 3-17; GARí, B., SOlER SAla, M., SANCho Planas, M., Delfi, I., NiETo, I., Y Rosillo LuQue, A., «Claustra. Propuesta metodológica para el estudio territorial del monacato femenino», Anuario de Estudios Medievales, 44.1 (2014), pp. 21-50.

${ }_{17}$ «Al llegar allí los siervos de Dios comprendieron que aquel lugar, por ser el más despreciable e inaccesible a la gente del mundo, era el más adecuado para el género de vida que con tanto empeño y desde hacía mucho tiempo habían pensado y por cuyo motivo habían llegado hasta allí», Exordium Parvum, Capítulo III; Exordium Cistercii, Capítulo II; TORRE, J. M", "El carisma cisterciense y bernardino", en Obras completas de San Bernardo I. Introducción general y tratados $\left(1^{\circ}\right)$, Edición preparada por los monjes cistercienses, Biblioteca de Autores Cristianos, Madrid, 1993, p. 31.

${ }^{18}$ GARCÍA DE CORTÁZAR Y RUIZ DE AgUIRRE, J. A., y TEJA CASUSO, R. (coords.), Monasterios y monarcas: fundación, presencia y memoria regia en los monasterios hispanos medievales, Fundación Santa María la Real, Aguilar de Campoo, 2012; García de Cortázar y Ruiz de Aguirre, J. A., y Teja Casuso, R. (coords.), Los monasterios medievales en sus emplazamientos: lugares de memoria de lo sagrado, Fundación Santa María la Real, Aguilar de Campoo, 2016; AILLET, C., «El monasterio de Lorvao y los confines de la Beira (siglos IX-XII). Apuntes sobre la memoria histórica de un espacio de contacto», Studia Historica. Historia Medieval, 27.1 (2011), pp. 71-95; CABRÉ I PAIRET, M., «De la leyenda a la autoría colectiva. A propósito de la versión aragonesa de la 'Crónica de Sant Pere de les Puel·les'», en Las mujeres de la 
Corona, la nobleza y los poderes urbanos ${ }^{19}$, a lo largo de la Edad Media y de la Edad Moderna $^{20}$.

En este trabajo introduciremos algunos ejemplos relativos a cuatro monasterios del Císter femenino castellano: San Andrés de Arroyo y Santa María de Cañas y la formación progresiva de la identidad de sus primeras abadesas ${ }^{21}$, San Vicente el Real de Segovia y la reconstrucción de su pasado institucional, y Santa María de Vileña y el registro del pasado heroico de la familia de su fundadora ${ }^{22}$. Nos encontramos, pues, ante relatos de amplia difusión, pero también frente a discursos aislados que podrían considerarse, al igual que han presentado Dacosta, Prieto y Díaz para el caso de la nobleza bajomedieval, «fragmentos de una memoria en construcción» dentro de una determinada cultura con unos valores concre$\operatorname{tos}^{23}$, siempre recopilados con una intención reflejada en sus presencias y ausencias, pero

Edad Media: actividades políticas, socioeconómicas y culturales, GARCÍA HERRERO, Mª C., y PÉREZ GALÁN, C. (coords.), Institución Fernando el Católico, Zaragoza, 2014, pp. 51-68; JORNET BENITO, N., «La relación con los recuerdos: la autoridad y el poder de la memoria», Las relaciones en la historia de la Europa medieval, RIVERA, Mª M. (ed.), Valencia, Tirant lo Blanch, 2006, pp. 17-57.

${ }^{19}$ Sobre la memoria en las instituciones eclesiásticas: TOMÁs FACI, G., «La construcción de la memoria escrita en los archivos eclesiásticos de Ribagorza (SS. XI-XIII)», Edad Media. Revista de Historia, 15 (2015), pp. 89-105. Sobre la memoria regia: MARTínEZ SOPENA, P., y RoDRÍGUEZ, A. (eds.), La construcción medieval de la memoria regia, Universidad de Valencia, Valencia, 2011; IsLA FrEZ, A., Memoria, culto y monarquía hispánica entre los siglos X y XII, Universidad de Jaén, Jaén, 2006. Sobre la memoria nobiliaria: Señalamos los ejemplos de VVAA., Discurso, memoria y representación: la nobleza peninsular en la Baja Edad Media. XLII Semana de Estudios Medievales Estella-Lizarra, 21-24 de julio, Gobierno de Navara, Pamplona, 2015. CARRIAZO, J. L., La memoria del linaje: los Ponce de León y sus antepasados a fines de la Edad Media, Universidad de Sevilla, Sevilla, 2002; REI, A., Memória de espaços e espaços de memória: de Al-Râzî a D. Pedro de Barcelos. Ediçôes Colibri, Lisboa, 2008; DACOSTA, A., PRIETO LASA, J. R., y DÍAZ DE DURANA, J. R. (coords.), La conciencia de los antepasados. La construcción de la memoria de la nobleza en la Baja Edad Media, Marcial Pons, Madrid, 2014; RoDRÍGUEZ LóPEZ, A., «Parentesco, memoria y poder. Una aproximación a los debates recientes sobre la Edad Media», en DEL VAL VALDIVIESO, M I. y MARTíneZ SOPENA, P., (coords.), Castilla y el mundo feudal: homenaje al profesor Julio Valdeón. Vol. 1. Junta de Castilla y León, Valladolid, 2010, pp. 77-94; Sobre la memoria urbana: CAVERO DomíngueZ, G. (coord.), Construir la memoria de la ciudad: espacios, poderes e identidades en la Edad Media (XII-XV), Universidad de León, León, 2017.

${ }^{20}$ Véase: Pollman, J., Memory in early modern Europe, 1500-1800, Oxford University Press, Oxford, 2017; URQUíZAR HERRERA, A., «La dureza y la constancia del papel. Los usos artísticos en la memoria escrita de la nobleza española de la Edad Moderna», Trocadero: Revista de Historia Moderna y Contemporánea, 19 (2007), pp. 69-93; PALOMO, F., «Memoria, cultura manuscrita y oralidad en la cronística franciscana portuguesa de la Edad Moderna», Tiempo, 22.41 (2016), pp. 509-532.

${ }^{21}$ Sobre el parentesco de doña Mencía: CANAL SÁnCHEZ-PAGín, J. M., «La Casa de Haro en León y Castilla durante el siglo XII. Nuevas conclusiones», Anuario de Estudios Medievales, 25.1 (1995), pp. 3-38; y YÁÑEZ NEIRA, D., «La Condesa Doña Mencía de Lara», Hidalguía: la revista de genealogía, nobleza y armas, 292-293 (2002), pp. 491-512. Sobre la condesa doña Urraca de Cañas véase BAURY, G., «Sainteté, mémoire et linage des abbesses cisterciennes de Castille au XIIIe S. La comtesse Urraca de Cañas (Ac. 1207-1262)», Anuario de Estudios Medievales, 41.1 (2011), pp. 151-182; ABAD LEON, F., Real Monasterio de Cañas. Nueve siglos de fidelidad, Ochoa, Logroño, 1984; MARCOS PASCUAL, E., Historia y jurisdicción de las abadesas del monasterio de Cañas, Instituto de Estudios Riojanos, Logroño, 2017, pp. 140-146.

${ }^{22}$ Sobre la reina doña Urraca de León: ÁlvareZ PADILlA, J., Reina y fundadora. Apuntes históricos sobre el Monasterio Cisterciense de Vileña, Diputación Provincial de Burgos, Burgos, 1945. Sobre el monasterio de Vileña en su contexto fundacional véase BAURY, G., Les religieuses de Castille. Patronage aristocratique et ordre cistercien XIIe XIIIe siècles, Presses Universitaires de Rennes, Rennes, 2012.

${ }^{23}$ Dacosta, A., Prieto LASA, J. R., y DÍAZ DE DurAnA, J. R., «Introducción. La materia genealógica como historia», en La conciencia de los antepasados. La construcción de la memoria de la nobleza en la 
forjados sobre una realidad de base indiscutible. Proponemos, por tanto, que estos mecanismos se utilizaron con la intención de afianzar la posición de unos monasterios dirigidos por abadesas mitradas con gran potestad religiosa, jurídica y territorial ${ }^{24}$, cuya autoridad pudo verse cuestionada y limitada por instituciones externas en distintos momentos de crisis y reforma religiosa ${ }^{25}$, ante la que las grandes abadías cistercienses femeninas desearían conservar su esencia anterior ${ }^{26}$, tal como veremos en el ejemplo segoviano. También fueron un medio de afianzar la identidad del monasterio como institución y como familia sobre una fundación ejemplar, como sucedió en Cañas y en Arroyo $^{27}$.

De esta manera, las abadías femeninas pudieron mostrar su asociación a las grandes figuras fundacionales de prestigio histórico reconocido, la valía espiritual y temporal de sus primeras abadesas y la vigencia de unos privilegios que, desde su etapa inicial, les otorgaron una posición privilegiada y cohesionaron la comunidad ${ }^{28}$. Además, frente a las narraciones

Baja Edad Media, Dacosta, A., Prieto LAsA, J. R., y DíAz de DuRAnA, J. R. (coords.), Marcial Pons, Madrid, 2014, p. 13.

${ }^{24}$ Sobre la jurisdicción abacial: ANDRÉs MARTín, M., «Pleito entre la Abadesa de San Andrés de Arroyo, el Condestable de Castilla y la villa de Herrera de Pisuerga sobre jurisdicción civil y criminal (1529-1549)», PI7TM, 71 (2000), pp. 395-410. Sobre la potestad abacial: EsCRIVÁ DE BALAGUER, J. M., La abadesa de las Huelgas, Luz, Madrid, 1974; PÉREZ CARAZO, P., El Monasterio de Santa María de Herce y su señorío abacial durante la Edad Media (1246 -1500), Tesis Doctoral dirigida por Manuel Fernando Ladero Quesada y leída en la UNED, 2001; Santa María de Herce y su abadengo en la Edad Media. Instituto de Estudios Riojanos, Logroño, 2008; MARCOS PASCUAL, E., Estudio histórico-canónico de la jurisdicción eclesiástica "nullius dioecesis" de las Ilmas. Sras. Abadesas del Monasterio de Cañas, Tesis doctoral presentada en la UNED, directoras: Remedios Morán Martín y María Teresa Regueiro García, 2015; MARCOS PASCUAL, E., «Jurisdicción nullius dioecesis», e-SLegal History Review, 21 (2015); Historia y jurisdicción...; BANGO TORVISO, I., «Las pretensiones episcopales de las abadesas cistercienses», en Mujeres en silencio: el monacato femenino en la España Medieval, GARCÍA DE CORTÁZAR Y RUIZ DE AGUIRRE, J. A., y Teja CAsuso, R. (coords.), Fundación Santa María la Real, Aguilar de Campoo, 2017, p. 227.

${ }^{25}$ Este es uno de los aspectos por los que ya durante la Alta y la Plena Edad Media las comunidades monásticas exaltaron «su identidad, para hacerse un hueco frente a los otros», y no dudaron en «desfigurar los hechos ni, llegado el caso, en inventárselos». GARCíA TURZA, J., «Los monjes...», pp. 123-124. Sobre la reforma religiosa, véase MARTínEZ ÁNGEL, L., «Sobre la reforma del Císter castellano (siglo XV): Juana de Cuéllar, Abadesa de Santa María y San Vicente el Real de Segovia», Cistercium: Revista cisterciense, 231 (2013), p. 391-400; CANABAL RODRÍGUEZ, L., «La aplicación de Trento en la vida regular: el convento femenino de San Clemente de Toledo», Cistercium: Revista cisterciense, 232 (2003), pp. 571-596; DIAGO HERNANDO, M., «Monasterios cisterciense femeninos en la ciudad de Valladolid a fines de la Edad Media», en Cistercium: Revista cisterciense, 209 (1997), pp. 819-836; CERRATO MATEOS, F., El Císter de Córdoba. Historia de una clausura, Universidad de Córdoba, Córdoba, 2006. Sobre reformas en el clero castellano: de NiETo SoriA, J. M., Iglesia y génesis del Estado Moderno en Castilla, Editorial Complutense, Madrid, 1993; GARCÍA ORO, J., La Reforma de los religiosos españoles en el tiempo de los Reyes Católicos, Instituto Isabel la Católica de Historia Eclesiástica, Valladolid, 1969; CASAS CASTELLS, E., «La arquitectura de las iglesias cistercienses en el Reino castellano-leonés: cambios y reformas estructurales en las mismas a partir del siglo XV», en I Congreso internacional de Monacato Femenino en España, Portugal y América, 14921992. Vol. 2., Viforcos Marinas, Ma I., y Paniagua PÉreZ, J., Universidad de León, León, 1993, pp. 459-476; RodRíGUEZ GonZÁLEZ, J. I., «El Císter femenino y la Congregación de Castilla: catálogo de la heráldica», Cistercium: Revista cisterciense, 265 (2015), pp. 97-234.

${ }^{26}$ JORNET BENITO, N., «La relación...», p. 44.

${ }^{27}$ En la educación: SCHLOTHEUBER, E., «Educación y formación, saber práctico y saber erudito en los monasterios femeninos en la Baja Edad Media», Anuario de Estudios Medievales, 44.1 (2014), pp. 313 y 325.

${ }^{28}$ JORNET BENITO, N., «La relación...», pp. 41-44. Para comprender este aspecto, debe atenderse a la fundación de dichos cenobios: Álvarez PAlEnZuEla, V. A., Monasterios cistercienses en Castilla (Siglos XII-XIII), Universidad de Valladolid, Valladolid, 1978; COELHO, M. F., Expresiones del poder feudal: El 
fantásticas que llegaron a construir algunos monasterios ya desde la Plena Edad Media ${ }^{29}$, así como importantes linajes nobiliarios como los $\mathrm{Haro}^{30}$, las elaboraciones del pasado plenomedieval que estudiaremos resultan no solo verosímiles, sino bien argumentadas - habida cuenta de las reformulaciones del parentesco de algunas fundadoras y de las omisiones intencionales-. Este hecho puede encontrar su explicación en las corrientes intelectuales de los momentos en los que se redactaron muchos de estos testimonios: el Humanismo y la Ilustración, donde los eruditos manifestaron un gusto creciente por la Historia bien hecha ${ }^{31}$. A ello se añade que la percepción que se tenía del pasado plenomedieval en la Baja Edad Media era diferente a la que se tuvo durante la Edad Moderna, pues era un elemento variable, adaptable y dependiente de las circunstancias de génesis del discurso, empleado para hacer frente a diferentes problemas ${ }^{32}$. Por tanto, cuando se recopilaba la historia medieval de un monasterio en una etapa posterior, siempre se hacía con una finalidad concreta y de forma selectiva, a menudo inconscientemente ${ }^{33}$.

Císter femenino en León (Siglos XII y XIII), Universidad de León, León, 2006; CAVERo DomínGUEZ, G., «El monasterio medieval, sede de solar nobiliario y refugio de mujeres de la aristocracia», en Monasterios y nobles en la España del románico: entre la devoción y la estrategia, GARCÍA DE CORTÁZAR Y RUIZ DE Aguirre, J. A., y Teja CAsuso, R. (coords.), Fundación Santa María la Real, Aguilar de Campoo, 2014, pp. 97-135; «El Císter femenino en los reinos de León y Castilla en los siglos XII y XIII», en Mujeres en silencio: el monacato femenino en la España Medieval, GARCÍA DE CORTÁZAR Y RUIZ DE AGUIRRE, J. A., y Teja Casuso, R. (coords.), Fundación Santa María la Real, Aguilar de Campoo, 2017, pp. 149-184; Alonso Álvarez, R., «Los promotores de la Orden del Císter en los Reinos de Castilla y León: familias aristocráticas y damas nobles», Anuario de Estudios Medievales (AEM), 37.2 (2007), pp. 653-710; BAURY, G., «Fundar una abadía cisterciense femenina a mediados del siglo XIII. En torno a los inicios de Otero (1230-1252)», Estudios Humanísticos. Historia, 13 (2014), pp. 9-34. Sobre el monacato femenino en la Edad Moderna: Cerrato Mateos, F., El Císter...; PÉrez Morera, J., «Renunciar al siglo: del claustro familiar al monástico. La funcionalidad social de los conventos femeninos», Revista de Historia Canaria, 20 (2005), pp. 159-188.

${ }^{29}$ GARCíA TURZA, J., «Los monjes...», p. 126 y ss.

${ }^{30}$ KRUS, L., «Una variante peninsular del mito de Melusina: el origen de los Haro en el Livro de Linhagens del Conde de Barcelos», en La conciencia de los antepasados. La construcción de la memoria de la nobleza en la Baja Edad Media, DAcostA, A., Prieto LASA, J. R., y DíAz DE DuRANA, J. R. (coords.), Marcial Pons, Madrid, 2014, pp. 17-42; PRIETO LASA, J. R., «La genealogía de los Haro en el Livro de Linhagens del Conde de Barcelos», Anuario de Estudios Medievales, 43.2 (2003), pp. 833-869. Sobre otros linajes: BECEIRO PITA, I., «La memoria y el discurso de la nobleza en los relatos genealógicos castellanos (13701540)», en La conciencia de los antepasados. La construcción de la memoria de la nobleza en la Baja Edad Media, Dacosta, A., Prieto Lasa, J. R., y Díaz de Durana, J. R. (coords.), Marcial Pons, Madrid, 2014, pp. 119-143; Quintanilla RASO, M C C., y CARCEller CERVIÑo, P., «La construcción...», pp. 271-302; AURELL, J., «Memoria dinástica y mitos fundadores: la construcción social del pasado en la Edad Media», en La conciencia de los antepasados. La construcción de la memoria de la nobleza en la Baja Edad Media, Dacosta, A., Prieto Lasa, J. R., y Díaz De Durana, J. R. (coords.), Marcial Pons, Madrid, 2014, pp. 303-334; DACOSTA, A., «El noble...», pp. 253-290.

${ }^{31}$ Un caso similar ha sido presentado por JORNET BENITO, N., «La relación...», pp. 46-47.

32 EsCALONA Monge, J., «Cartularios, memoria y discurso en la Castilla medieval», en La memoria del poder, el poder de la memoria, XXVII Semana de Estudios Medievales, Nájera, del 25 al 29 de julio de 2016, LÓPEZ OJEDA, E. (coord.), Instituto de Estudios Riojanos, Logroño, 2017, p. 168. Estos testimonios reelaboraban el pasado plenomedieval desde la Edad Moderna, por lo que no podemos asociar dichos escritos, aunque compartan ciertos elementos, a los pleno y bajomedievales, pues la conciencia del tiempo y la forma de hacer Historia eran diferentes, dado que desde la Baja Edad Media la gestión del tiempo se transformó, «exigiéndose una contextualización histórica de los relatos de fundación». DACOSTA, A., «El noble...», p. 287.

${ }^{33}$ Quintanilla Raso, Ma C., y CARCEller CerviÑo, P., «La construcción...», p. 271. 
Debemos preguntarnos, pues, cómo elaboraban estas comunidades su memoria en función de la interpretación de un pasado determinado, a qué presente daba respuesta ${ }^{34}$, quién ordenó elaborar dichos discursos, quién los generó, a quién iban dirigidos, a través de qué medios los difundieron, qué impacto y qué consecuencias tuvieron, y si se alejaron de la realidad con alguna intención o, por el contrario, fueron fieles a ella. Las manifestaciones correspondientes a la Edad Media y la primera Edad Moderna constituyeron de hecho «un medio de acercamiento del pasado al presente para legitimar y dar consistencia a una situación del momento presente», en el que la «falta de referentes cronológicos fijos en el pasado facilitaban esta proximidad» temporal, tratando de acercar la figura del fundador al momento de su recopilación, quizá no solo por la ausencia de metodología rigurosa, sino intencionalmente $^{35}$.

Las manifestaciones que nos han llegado con mayor integridad son las fuentes escritas, que encontramos en las introducciones de libros becerros y cartularios, por ejemplo, en el Cartulario de Vileña ${ }^{36}$ o en el Becerro de San Vicente de Segovia ${ }^{37}$; crónicas y relaciones históricas dispersas, como las de Santa María de Vileña ${ }^{38}$, o noticias sueltas entre los documentos económicos del monasterio, tal como sucede también en San Vicente ${ }^{39}$. En segundo lugar, contamos con un amplio registro material, que a menudo aparece reflejado en las fuentes escritas como elemento de autoridad ${ }^{40}$, pero que contaba con un notable efecto de difusión visual tanto en sí mismo como en su emplazamiento ${ }^{41}$. Los epígrafes, elemento mixto entre lo escrito y lo visual, no destacan por su abundancia en el Císter ${ }^{42}$, aunque son llamativos algunos ejemplos en los monasterios de San Andrés de Arroyo, Santa María de Cañas o San Vicente el Real, destinados a mostrar la historia del edificio y de su comunidad ${ }^{43}$. Por su

\footnotetext{
${ }^{34}$ Aurell, J., «Memoria dinástica...», p. 326; MARTIN, G., «Pasados...», p. 18.

35 AURELL, J., «Memoria dinástica...», p. 326.

${ }^{36}$ AHN, Clero, Códices, L. 1168, f. 0. (S. XVIII-S.XIX)

${ }^{37}$ AHN, Clero, L. 11974, s/f. (S. XVIII)

${ }^{38}$ BNE, Ms. 13127, ff. 182-189. (1544-1579)

${ }^{39}$ AHN, Clero, L. 12062, ff. 1r y 1v. (1726-1728)

${ }^{40}$ AHN, Clero, L. 12062, ff. 1r y 1v; AHN, Clero, L. 11974, s/f.

${ }^{41}$ En la iconografía del sepulcro de Urraca Díaz de Cañas se refleja parte de la vida de la condesa. Sobre estos aspectos y la memoria de los Haro ligada a los monasterios de Vileña, Cañas y Herce ha escrito BAURY, G., Les religieuses..., pp. 75-90.

${ }^{42}$ MARTín LÓPEZ, M ${ }^{a}$ E., "Las inscripciones en el monacato hispano: contexto, mensaje e intencionalidad", en Lugares de escritura: el monasterio, BALDAQUÍ ESCANDELL, V. R. (ed.), Universidad de Alicante, Alicante, 2016, pp. 153-175; MARTín LóPEZ, Ma E., y GARCÍA LOBO, V., «De Epigrafía Medieval. Introducción y álbum», Cistercium: Revista cisterciense, 204 (1996), pp. 159-161; PEREIRA GARCÍA, I., «La epigrafía en el monacato cisterciense: el ejemplo del Monasterio de Santa María de Cañas», Espacio, tiempo, forma, Serie III Historia Medieval, 28 (2015), pp. 413-439; GARCÍA LOBO, V., «La publicidad en el Císter: las inscripciones de Santa María de Moreruela», en Moreruela: un monasterio en la historia del Císter, LARRÉn IZQUIERDO, H. (coord.), Junta de Castilla y León, León, 2008, pp. 97-115; GARCÍA LOBO, V., «De epigrafía cisterciense. Las inscripciones del monasterio de Carracedo», Cistercium: Revista cisterciense, 208 (1997), pp. 189-206; SANTIAGO FERNÁNDEZ, J., «Comunicación publicitaria en el monasterio cisterciense de Nuestra Señora de Monsalud en Córcoles (Guadalajara)», Hispania Sacra, 64.129 (2012), pp. 67-96. Sobre San Andrés de Arroyo, Nota 48; sobre San Vicente de Segovia, Nota 50.

${ }^{43}$ Sobre las inscripciones en Arroyo: MARTín LÓPEZ, Ma E., «Epigrafía cisterciense: las inscripciones del monasterio de San Andrés de Arroyo», Cistercium: Revista cisterciense, 208 (1997), pp. 489-508; MARTÍNEZ ORTEGA, R., «Epigrafía Medieval: tres inscripciones de San Andrés de Arroyo y el rey Alfonso Onceno
} 
parte, la heráldica fue empleada como exaltación de los fundadores, abadesas y promotores de los monasterios a través de su linaje, trayectoria y poderío, y estaba colocada en lugares escogidos para ser vista por quienes accedieran a los distintos niveles del monasterio: entrada principal, puertas de acceso a los edificios auxiliares, claustro - pavimento, insertos en las pandas Este y Sur-, sepulcros de la Sala Capitular, estructuras funerarias de la iglesia, etc., por lo que es preciso estudiarla en su contexto ${ }^{44}$. Encontramos igualmente algunos casos en los que, ante el vacío documental y material de una etapa histórica concreta, en un momento de necesidad de difusión del pasado medieval, las comunidades pudieron recurrir a un pasado verosímil pero no siempre fiel a la realidad, plasmando su memoria a través de evidencias que en la actualidad podrían llegar a resultarnos de dudosa autoridad, pero que entonces tuvieron el efecto deseado y se consideraron adecuadas, tal como veremos en los ejemplos procedentes de San Vicente de Segovia ${ }^{45}$.

(1312-1350)», Revista de Filología, 21 (2003), pp. 219-238; GARCíA LOBO, V., "La publicidad en el Císter", en Monjes y monasterios. El Císter en el medievo de Castilla y León, BANGO TORVISO, I. (coord.), Junta de Castilla y León, Valladolid, 1998, pp. 47-66; GuTIÉRREZ PAJARES, M. T., El monasterio cisterciense de San Andrés de Arroyo, Diputación Provincial de Palencia, Palencia, 1993, pp. 30-33. Sobre las inscripciones en Cañas: PEREIRA GARCÍA, I., «La epigrafía...». Sobre las inscripciones en San Vicente: CASAs CAstells, E., y PAlomo FernándeZ, G., «Santa María y San Vicente el Real», en Segovia cisterciense: estudios de historia y arte sobre los monasterios segovianos de la orden del Císter. Noveno centenario del nacimiento de Bernardo de Claraval: catálogo de la Exposición, Monasterio de Santa María y San Vicente el Real, Segovia, 1991, pp. 35-38. Solían encontrarse en lugares visibles, tal como sucede en San Andrés de Arroyo, en el muro de cierre de la nave norte de la iglesia, aunque también en zonas de la clausura, como en la panda del refectorio de Santa María de Cañas. Sin embargo, no suelen figurar inscripciones en los sepulcros de las primeras abadesas y fundadoras debido al programa de austeridad inicial del Císter, que buscaba evitar distracciones para favorecer el acercamiento interior a la oración. PEREIRA GARCÍA, I., «La epigrafía...», p. 429; MARTíN LÓPEZ, Mª E., «De Epigrafía cisterciense...», pp. 489-508. Sobre la función política de la epigrafía: PENAS GONZÁLEZ, E., «Los ecos de la frontera: propaganda bélica y autoridad en el Císter femenino castellano», Actas del II Coloquio de Jóvenes Investigadores en Historia y Arqueología Militar, Cátedra de Historia Militar, Universidad Complutense de Madrid, 16-17 de marzo de 2018. (En prensa).

${ }^{44}$ Para el caso castellano-leonés: Vega PATO, T., «Presencia de la Virgen María en la heráldica Cisterciense (II): nuevas aportaciones», en Los caminos de Santiago y la vida monástica cisterciense: actas del IV Congreso internacional sobre el Císter en Portugal y Galicia, Vol. 2, GonZÁlez GARCíA, M. A. y AlBuRQuerQue CARREIRAS (dirs.), 2010, pp. 1061-1067; RodRÍGUEZ GonZÁlEZ, J. I., «La Heráldica de la Congregación Cisterciense de Castilla y el Monasterio de Santa María de Huerta», Hidalguía: revista de genealogía, nobleza y armas, 364-365 (2014), pp. 499-526; RUIZ DE BUCESTA Y ÁlVAREZ, M. L., y RoDRIGUEZ DE MARIBONA Y DÁVILA, M. Mª «Heráldica en el Real Monasterio Cisterciense de Santa María de San Salvador de Cañas», Boletín de la A.R.G.H., 7 (2015), pp. 139-162; RodRíGUEZ GonZÁlEZ, J. I., «Monasterio de Santa María de Ola: Plaza clave para entender la heráldica de la Congregación de Castilla», Glaucopis: Boletín del Instituto de Estudios Vigueses, 19 (2014), pp. 31-50; del mismo autor: «El Císter...», pp. 97-234. Sobre estudios heráldicos durante la Edad Moderna: RODRÍGUEZ GONZÁLEZ, J. I., «La heráldica de la Congregación Cisterciense de Castilla en la época de los Austrias (siglos XVI-XVII)», Hidalguía: la revista de genealogía y armas, 368 (2015), pp. 59-106; del mismo autor «La Heráldica de la Congregación Cisterciense de Castilla en la época de los Austrias (siglos XVI y XVII): (continuación y fin)», Hidalguía: la revista de genealogía y armas, 369 (2015), pp. 487-533; «La Heráldica de la Congregación Cisterciense de Castilla en la época de los Borbones (siglos XVIII y XIX)», Hidalguía: la revista de genealogía y armas, 370 (2015), pp. 771-846.

${ }^{45}$ Estos mismos aspectos han sido señalados, aunque para un contexto muy anterior en el que se recurría a construcciones míticas con el fin de completar y justificar etapas desconocidas, por GARCíA TURZA, J., «Los monjes...», p. 124. En el caso segoviano, el autor de uno de los textos llega a emplear obras de autores de reconocido prestigio historiográfico, tales como Diego de Colmenares (1586-1708), Gaspar Ibáñez de 


\section{LA FORMACIÓN DE LA IDENTIDAD ABACIAL: SAN ANDRÉS DE ARROYO Y SANTA MARÍA DE CAÑAS}

La abadía San Andrés de Arroyo figura por primera vez en dos documentos económicos fechados en 1181, en los que se presenta a la condesa y abadesa doña Mencía como cabeza de una comunidad monástica que estaba plenamente constituida ${ }^{46}$. Esto sugiere la anterioridad de su fundación a la fecha citada, seguramente en torno a $1175^{47}$. La primera abadesa y fundadora, cuya memoria nos ocupa, pasó a la historia como la condesa Mencía de Lara, viuda del conde Álvaro Pérez de Lara, por la heráldica de su sepulcro ${ }^{48}$, los castillos presentes el monasterio, una noticia conservada en el Libro Becerro ${ }^{49}$ — que la presenta como «infanta de Castilla, hermana que se dice de la infanta doña Verenguela, hijas ambas del rey don Alonso el séptimo» ${ }^{50}$ - , y un privilegio de Juan II fechado en 1410 que la menciona

Segovia (1628-1708) o Enrique Flórez (1702-1773), así como fuentes arqueológicas. AHN, Clero, L. 11974 , s/f.

${ }^{46}$ AMSA, Cajón 41; AHN, Sellos 1-4, en GonZÁLEZ, J., El Reino de Castilla en la época de Alfonso VIII. Vol. 2, CSIC, Madrid, 1960, Doc. 366, pp. 631-633; YÁÑEZ NEIRA, D., «La condesa...», p. 500.

${ }^{47}$ En 1174 la condesa doña Mencía firma en segundo lugar, tras su hermana Sancha, la donación de Zarratón, que su madre realizó al monasterio de Cañas. AHN, Clero, Car. 1023, Doc. 20, edit. por MARCOS PASCUAl, E., Historia..., Apéndice documental, Doc. 9, p. 37; ABAD LEÓN, F., Real..., pp. 71-74. MARCOS PASCUAL, E., Historia..., p.88, propone que el orden de aparición de los hijos corresponde a su nacimiento. En este momento era viuda y la única hija casada del matrimonio de don Lope y doña Aldonza, pues solo a ella se la intitula como condesa y su nombre está precedido por «donna». Se ha propuesto que su matrimonio duró hasta 1173-1174. BAURY, G., Les religieuses..., p. 54; AlONSO ÁlvareZ, R., «Los promotores...», p. 673. Consideraremos, sin embargo, que el conde falleció en 1173, dado que este mismo año doña Mencía permutó con Alfonso VIII el monasterio de San Martín de Amaya por la villa de «Sancti Andrei». ¿Se trataba del emplazamiento del futuro monasterio de San Andrés de Arroyo? AMSAR, Cajón 31, en GonZÁlez, J., El Reino... Vol. 2, Doc. 186, pp. 310-312. Por su parte, Yáñez Neira señala que solo una mujer podía ser considerada condesa si se desposaba con un conde. YÁñEZ NEIRA, D., «La condesa...», pp. 496-497. Así lo ha indicado también ABAD LEÓN, F., Real..., p. 73. Si se trataba de la segunda hija de un matrimonio que contrajo nupcias a mediados de la década de 1150, nacería en torno a 1156, enviudando a los 17 años y necesitando un año para realizar el noviciado, seguramente en Cañas o, como ha apuntado YÁÑEZ NEIRA, D., «La condesa...», pp. 502-502, en el mismo San Andrés de Arroyo.

48 Sobre el enterramiento: FERNÁNDEZ GONZÁLEZ, E., «Los sepulcros de la sala capitular del monasterio de San Andrés del Arrollo (Palencia)», Estudios Humanísticos, 1 (1979), pp. 83-98; de la misma autora: «Una tela hispano musulmana en el sepulcro de doña Mencía de Lara del Monasterio cisterciense de San Andrés del Arroyo», Actas de las II Jornadas de Cultura Arabe e Islámica: (1980), Instituto Hispano-Árabe de Cultura, 1985, pp. 197-220; BANGO TORVISO, I., «Las pretensiones...», pp. 223-253; YÁñEZ NEIRA, D., «La condesa...», p. 497. Por la iconografía del sepulcro el obispo Enrique Almaraz consideró que doña Mencía «fue nieta de algún magnate de los condes de Lara, quizá de don Rodrigo González», en FERNÁNDEZ GonZÁlez, E., «Los sepulcros...», p. 84. Sobre don Álvaro Pérez de Lara, tenente de Asturias y Santillana en 1160-1170, véase EsTEPA DíEZ, C., «Las tenencias en Castilla y León en los siglos XI al XIII», en Los espacios del rey. Poder y territorio en las monarquías hispánicas (siglos XII-XIV), ARIAS GuILlÉN, F., y MARTínez SoPEnA, P. (eds.), Universidad del País Vasco, Bilbao, 2018, pp. 51-53.

${ }^{49}$ AMSAR, Libro Becerro. En muchas ocasiones, durante la Baja Edad Media se trató de otorgar a la cabeza del linaje un origen de sangre real. QuintANILla RASO, $\mathrm{M}^{\mathrm{a}} \mathrm{C}$., y CARCELlER CERVIÑO, P., «La construcción...», p. 276. En este caso, doña Mencía encabezó un linaje monástico.

${ }^{50}$ Noticia recogida por FERNÁNDEZ GONZÁLEZ, E., «Los sepulcros...», pp. 83-84. 
como «señora que fue de Lara» ${ }^{51}$, llegándosela a considerar biznieta de Alfonso VI. Sin embargo, son aspectos que no fueron mencionados en la documentación de la época, teniendo en cuenta la importancia que se otorgaba a la sangre real ${ }^{52}$. Por ello, autores como Lambert, Rodríguez Muñoz ${ }^{53}$, José María Canal ${ }^{54}$ y Damián Yáñez Neira ${ }^{55}$, basándose en la documentación procedente del monasterio de Cañas, donde figura entre los hijos del matrimonio fundador — Lope Díaz de Haro y Aldonza Ruiz de Castro — una «comissa donna Mencia» ${ }^{56}$, así como en la heráldica de San Andrés de Arroyo, concluyeron que Mencía de Lara y Mencía López de Haro compartían una misma identidad que en la Baja Edad Media se dividió en dos. La primera de ellas estuvo presente hasta 1174 y la segunda a partir de esta misma fecha, constituyendo ambas la figura de una de las mujeres más válidas de su época. Doña Mencía fue, por tanto, no solo la señora de Lara, sino la segunda hija de Lope Díaz I de Haro y su segunda esposa, Aldonza Ruiz de Castro, viuda, como dijimos, del conde Álvaro Pérez de $\operatorname{Lara}^{57}$.

Independientemente de su parentesco, nos hallamos ante una mujer de grandes cualidades, pues como sostuvo Yáñez Neira en su estudio recopilatorio sobre la historia de esta condesa $^{58}$, su identidad traspasó el mero hecho linajístico para llegar a ser considerada como santa o incluso como virgen ${ }^{59}$, dependiendo del momento histórico en el que se evocase la memoria de su figura ${ }^{60}$. Se la dotó, pues, de virtudes que se han recordado hasta épocas muy recientes y que, aunque carezcan de una base material y documental, sí poseen un componente real: el recuerdo de una mujer de excepcional personalidad espiritual y gubernativa que

\footnotetext{
${ }^{51}$ YÁÑEZ NEIRA, D., «La condesa...», p. 493; FERNÁNDEZ GONZÁLEZ, E., «Los sepulcros...», p. 84. Esta mención refleja que a inicios del siglo XV ya era más conocida Mencía de Lara que Mencía López de Haro, aunque es presentada como «señora que fue de Lara», lo cual fue cierto, y no como miembro de dicho linaje.

52 YÁÑEZ NEIRA, D., «La condesa...», p. 493.

${ }^{53}$ Ambos en YÁÑEZ NEIRA, D., «La condesa...», pp. 495 y 498, respectivamente.

${ }^{54}$ CANAL SÁNCHEZ-PAGÍN, J. Mª , «a Casa...», pp. 22-25.

55 YÁÑEZ NEIRA, D., "La condesa...", pp. 491-492.

${ }^{56}$ El documento está fechado en 1174. AHN, Clero, Carp. 1023, Doc. 20, edit. por MARCOS PASCUAL, E, Enrique: Historia..., Apéndice documental, Doc. 9, p. 37; ABAD LEÓN, F., Real..., pp. 71-74.

${ }^{57}$ BAURY, G., Les religieuses..., p. 54; AlONSO ÁlVAREZ, R., «Los promotores...», p. 673; CANAL SÁNCHEZ-PAGín, J. Mª «La casa...», pp. 22-25; YÁÑEZ NEIRA, D., «La condesa...», pp. 496-497; CAVERO DomínguEZ, G., «El monasterio...», p. 123. La condesa doña Mencía pudo también confundirse con su sobrina nieta homónima, hija de Lope Díaz II de Haro y esposa de Álvaro Pérez de Castro, enterrada en la Capilla de la Vera Cruz en el monasterio de Santa María la Real de Nájera. En el documento de la BNE que presentaremos para analizar la memoria de doña Urraca de Vileña, Fray Pedro Ponce de León alude a una hermana de la reina llamada doña Mencía: «Y a doña dicen que esta doña Mençía, que fue casada con don Ruy Gutiérrez de Castro, gran señor de Galiçia, Mençía, que murió donçella», por lo que había noticias de su existencia, pero encarnada en una tercera identidad distinta a las dos que hemos presentado. BNE, Ms. 13127, f. 182 v.

${ }^{58}$ Sobre la personalidad de doña Mencía ha escrito YÁÑEZ NEIRA, D., «La condesa...», pp. 502-506.

59 Así lo indica YÁÑEZ NeIRA, D., «La condesa...», p. 492, al corregir la noticia transmitida por Felipe Seguino, quien indicó que profesó en San Andrés de Arroyo en «perpetua virginidad». Incluso se asignaron ambas cualidades a su sucesora, la condesa doña María, quien está claro que «fue tenida siempre como alma de sólidas virtudes», al igual que su tía y predecesora. YÁÑEZ NEIRA, D., «La condesa...», p. 507.

${ }^{60}$ Durante la Edad Moderna se resaltaron estas virtudes para presentar a las fundadoras como modelo a seguir. Así ocurrió en el caso de Urraca Díaz de Haro. BAURY, G., «Sainteté...», p. 176-179. Pero también se observa en otros casos: JORNET BENITO, N., «La relación...», p. 42.
} 
se ha transmitido de generación en generación dentro del monasterio y de la Orden Cisterciense $^{61}$.

Debemos preguntarnos si esta distorsión de su parentesco fue fruto de una tradición adquirida de forma progresiva tras su muerte, de una memoria identitaria asumida por sus sucesoras, o incluso de una desvinculación familiar intencional llevada a cabo por doña Mencía en vida y que dio lugar a un vacío de información acerca de su linaje paterno, pues, salvo su escudo ${ }^{62}$, no se conservan apenas evidencias de su pertenencia a la familia Haro una vez fundado el monasterio. Por otro lado, si atendemos a la colocación y naturaleza de su sepulcro, observamos que es posterior a su muerte, aunque también medieval, y de la misma factura que el de su sobrina y sucesora, la condesa María Díaz de Haro, abadesa entre 1228 y 1266, aunque este enterramiento es de estilo más sencillo ${ }^{63}$. Otra interpretación que, aunque arriesgada, resulta plausible, teniendo en cuenta la lealtad de doña Mencía hacia el rey ${ }^{64}$, es que tanto ella como sus sucesoras pudieron, o bien emplear los linajes Lara y Haro estratégicamente para favorecer al monasterio, o bien desvincularse de ambas familias con el fin de posicionarse junto a la monarquía, evitando así entrar en los conflictos nobiliarios protagonizados, entre otras figuras, por el hermano de doña Mencía, Diego López II de Haro ${ }^{65}$, por su hermana Urraca López de Haro — viuda de Fernando II de León y fundadora de Vileña—, a

\footnotetext{
${ }^{61}$ Una noticia de 1664 indica que anualmente se celebraban dos memorias por la fundadora: el 12 de marzo y el 22 de noviembre. FERNÁNDEZ GONZÁLEZ, E., «Los sepulcros...», p. 85. La admiración hacia doña Mencía consta en las obras de MANRIQUE, A., Cisterciensium ecclesiasticorum: annalium a condito cistercio, Westmead Hants, Gregg, 1970 (1º ed, 1642); MASOLIVER, A., San Andrés de Arroyo. Historia y arte, Monasterio de San Andrés de Arroyo, Palencia, 1985; o YÁÑEZ NEIRA, D., «La condesa...», entre otros eclesiásticos y monjes cistercienses. El himno que la comunidad cantaba a la condesa aún se conserva en el repertorio musical contemporáneo del monasterio.

${ }^{62}$ En la puerta de la hospedería, del siglo XVIII; flanqueando la entrada de la Sala Capitular y en la Panda Sur. Contiene en su parte izquierda una $\mathrm{X}$ en la que se alternan las calderas de los Lara y dos castillos, en su parte derecha superior los lobos de los Haro, y en su parte derecha inferior los tres tejos de Guipúzcoa. Yáñez Neira sugiere que es contemporáneo a la fundación del edificio, YÁñEZ NEIRA, D., «La condesa...», p. 497, si bien la lectura de alzados evidencia que estos emblemas se insertan en fases correspondientes a reformas de los siglos XVI y XVIII, aunque es probable que se reutilizasen o que reproduzcan una heráldica previa.

63 YÁÑEZ NEIRA, D., «La condesa...», p. 497, sugiere que el sepulcro de doña Mencía podría fecharse en el siglo XIV. Sin embargo, FERNÁNDEZ GONZÁlEZ, E. «Los sepulcros...», pp. 86 y 91, data ambos enterramientos en el siglo XIII por el estilo de su factura, sugiriendo que la misma doña Mencía puede estar representada a la derecha de la imagen del frontón de la tapa.

${ }^{64}$ YÁÑEZ NEIRA, D., «La condesa...», p. 503.

${ }^{65}$ Sobre la controvertida personalidad política de este magnate: BNE, Ms. 13127, ff. 182-189, y los trabajos de BAURY, G., «Diego López "Le bon”, Diego López "Le mauvais". Comment s'est construite la mémoire d'un magnat tu règne d'Alphonse VIII de Castille», Berceo, 144 (2003), pp. 37-92; «Los ricoshombres y el rey en Castilla: el linaje Haro (1076-1322)», Territorio, Sociedad y Poder, 6 (2011), pp. 53-73. La fama de Diego López II y su enfrentamiento con Alfonso VIII, agudizado entre 1201 y 1205, han sido tratados por KRUS, L., «Una variante...», p. 33. Fue entonces cuando se trató de realzar la figura del cabeza del linaje con relatos legendarios. KRUS, L., «Una variante...», p. 34. La memoria de Diego López de Haro y su exaltación como héroe de las Navas a partir del siglo XV ha sido analizada por BAURY, G., «Diego...», pp. 80 y ss.
} 
la que nos referiremos más adelante, y por Álvaro y Gonzalo Núñez de Lara, maridos de las también hermanas doña Urraca de Cañas y doña María de San Andrés ${ }^{66}$.

Sin embargo, la respuesta puede estar detrás de un hecho mucho más profundo y sencillo: la humildad personal de la condesa, quien era consciente de su importancia en el panorama político castellano, pero también de su condición de religiosa, que eligió con preferencia a un segundo matrimonio. De esta manera, hay evidencias para considerar que fundó San Andrés, a diferencia de su hermana en Vileña, no para propiciar la memoria de su linaje y servirle como refugio económico y político ${ }^{67}$, sino para consagrarse a Dios. Por su obediencia y apoyo incondicional al rey, cuyo poder se consideraba entonces de origen divino, doña Mencía sometió su propia fundación materna al monasterio real de Las Huelgas ${ }^{68}$, lo que deja ver la amplia visión unificadora que la condesa tenía de la Orden Cisterciense, del Reino de Castilla y de la finalidad de su propio monasterio, que ideó con un trasfondo claramente vocacional. Por ello, no es de extrañar que su lealtad fuese apreciada y ampliamente premiada por la Corona ${ }^{69}$, llegando a ser testamentaria de Alfonso VIII, consejera y visitadora de Las Huelgas de Burgos ${ }^{70}$, lo que evidencia la gran confianza que el rey tenía puesta en ella tanto en asuntos de gobierno como en la corrección de la observancia religiosa de la fundación burgalesa, concebida como modelo a seguir.

Pero la división de la identidad de doña Mencía no constituye un caso único, pues encontramos un ejemplo muy similar en la figura de su sobrina, la también condesa y abadesa

\footnotetext{
${ }^{66}$ Así lo indica SAlazAR y CASTRO, L., Historia genealógica de la casa de Lara. Vol. 1, Imprenta Real, Madrid, 1696, p. 242; SALAZAR Y CASTRO, L., Historia..., Vol. 2. Libro XVI, p. 63, quien añade que ambas eran hijas de la segunda esposa de don Diego, Toda Pérez de Azagra.

${ }^{67}$ Sobre estos aspectos: CAVERo DoMíngUEZ, G., «El monasterio...», pp. 127-129.

${ }^{68}$ No consta en ningún documento su filiación a Tulebras, Cañas o Perales, ni que la primera comunidad procediese de alguno de estos monasterios. Estos aspectos, junto con algunas propuestas, han sido señalados por YÁÑEZ NEIRA, D., «La condesa...», pp. 499-502, entre otros autores. Por otro lado, son numerosos los investigadores que se han referido al primer Capítulo en Las Huelgas, por lo que nos limitaremos a citar los documentos que así lo evidencian: AMHB, Leg. 8, Doc. 277, en LIZOAIN GARRIDO, J. M., Documentación del monasterio de Las Huelgas de Burgos (1116-1230). Garrido Garrido, Burgos, 1985, pp. 46-48, Doc. 24; AMHB, Leg. 21, Doc. 783, en LizOAIN GARRIDO, J. M., Documentación..., pp. 48-51, Doc. 25.

${ }^{69}$ Doña Mencía fue citada en una donación que Alfonso IX realizó al monasterio, concediéndole la villa de La Vid, como "venerabilis amice nostre comitisse done Mencie, que nobis grate semper extitit et merito fidelitatis et laudabilis devotione servicii", en PÉREZ-EMBID WAMBA, J., «El Císter femenino en Castilla y León. La formación de los dominios (siglos XII - XIII)», En la España Medieval, 9 (1986), p. 774.

${ }^{70}$ Siempre figurando como testamentaria en tercer lugar, tras el Arzobispo de Toledo, Rodrigo Jiménez de Rada, y el Obispo de Pelancia, don Tello, con la fórmula: «mutans testamentarios et potestatem quam predictis quatuor contulerat in hos mutauit, scilitet, in dominum Rodericum, Toletanum archiepiscopum, et in dominum Tellium Palentinum, et in dominam Menciam comitissam, abbatissam Sancti Andree de Arroyo». AHN, Liber Privilegiorum, Tolet. Ecc., I. ff. 26v-27, en GonZÁleZ, J., El Reino... Vol. 3, Doc. 969, pp. 672-675; AC, Palencia, 3-2-7, en GonZÁleZ, J., El Reino... Vol. 3, Doc. 971, pp. 677-678. El testamento está fechado en 1214, noviembre, 8. Doña Mencía figura como consejera en una transacción entre el abad de Oña, el Monasterio de Mave y Las Huelgas. AMHB, Leg. 36, Doc. 1763, en LIZOAIN GARrido, J. M., Documentación..., pp. 208-209, Doc. 137. Figura como visitadora en ViVANCOS, M. C., «El Beato de San Andrés de Arroyo», en Beato de Liébana, códice del Monasterio de San Andrés de Arroyo, Vivancos, M. C., Ocón, D., Bernis, C., y MiRAndA, C., Moleiro, Madrid, 1998, p. 57; MANRIQUE, Á., Annales Cistercienses, en FERNÁNDEZ GONZÁLEZ, E., «Los sepulcros...», p. 84.
} 
Urraca Díaz de Haro ${ }^{71}$. El texto al que nos vamos a referir para resaltar este ejemplo se encuentra en la primera página del Cartulario de Vileña ${ }^{72}$, y consiste en un párrafo introductorio tardío al que se añadió una nota posterior en su parte final, pudiendo datarse ambas intervenciones en los siglos XVIII o $\mathrm{XIX}^{73}$. En esta reseña anónima, cuya intención puede ser contextualizar históricamente el Cartulario del siglo XIII en un momento en el que continuaba en uso $^{74}$, se alude también al monasterio de Cañas, punto de referencia familiar, y a los padres de la reina Urraca de Vileña. Los cartularios, como ha señalado Julio Escalona, eran fuentes de acceso limitado e inadecuadas para transmitir información, aunque eran también empleados para enseñar, conservar la memoria en momentos posteriores ${ }^{75}$, o evitar la pérdida del recuerdo histórico del monasterio y su fundadora, lo que concuerda con la presencia de esta noticia.

La intervención posterior consiste en una corrección sobre la figura de la condesa doña Aldonza, lo que refleja una preocupación no solo por mantener la veracidad de los hechos, sino también su fidelidad histórica. Sin embargo, en este fragmento se confunde un parentesco que ya debía de estar asumido como tal en el momento de su redacción ${ }^{76}$ : el de la cuarta abadesa, Urraca Díaz de Haro, presentándola como hija menor de los fundadores, noticia que se ha aceptado como correcta hasta que se demostró la verdadera ascendencia de la condesa viuda de Álvaro Núñez de Lara ${ }^{77}$. Sin embargo, Luis de Salazar y Castro ya indicó la confusión existente en el momento de la redacción de su obra cumbre con el parentesco de doña Urraca — señaló que había una tendencia a llamarla Aldonza o a suplantar a su hermana Mencía-, identificándola correctamente como hija de Diego López de Haro, viuda de Álvaro Núñez de Lara y abadesa de Cañas ${ }^{78}$. Este hecho resulta igualmente interesante, puesto que en este monasterio se fue más allá: doña Urraca no solo se desdobló en dos identidades, sino que en un momento determinado se redefinió oficialmente parte de una de ellas: que era

\footnotetext{
${ }^{71}$ Sobre la evolución de la memoria de esta abadesa durante la Edad Moderna: BAURY, G., «Sainteté...».

72 AHN, Clero, Códices, L. 1168; RuIZ AsENCIO, J. M., «El códice diplomático del Monasterio de Vileña», en Homenaje a Don Agustín Millares Carlo, Confederación de Cajas de Ahorros, Las Palmas de Gran Canaria, 1975, pp. 57-68; PÉREZ DE TUDELA Y VELASCO, M. I., El monasterio de Vileña en sus documentos: el códice del A.H.N, Universidad Complutense de Madrid, Madrid, 1977; CADIÑANOS BARDECI, I., El Monasterio de Santa María la Real de Vileña. Su Museo y Cartulario, Caja de Ahorros Municipal de Burgos, Burgos, 1990. Apéndice documental, Doc. 4.

${ }^{73}$ Ruiz Asencio ha identificado varios amanuenses. RuIZ ASENCIO, J. M., «El códice...», p. 60 y 67. Proponemos que dos de ellos (siglos XVIII y XIX) pudieron estar detrás de las intervenciones introductorias.

${ }^{74}$ RUIZ ASENCIO, J. M., «El códice...», pp. 57 y ss. Sobre las numerosas vidas y utilidades que puede tener un cartulario ha escrito ESCALONA MONGE, J., « Cartularios....», pp. 167-168.

${ }^{75}$ ESCALONA MONGE, J., «Cartularios...», p. 201.

${ }^{76}$ BAURY, G., «Sainteté...», p. 153, defiende que la distorsión del parentesco de Urraca Díaz de Haro se materializó entre mediados del siglo XIV e inicios del siglo XVII.

77 Ballesteros Beretta, A., Alfonso X el Sabio. Barcelona, Salvat, ed. 1984, p. 27; CANAL SÁnCHEZPagín, J. M., «La Casa...», p. 81 y ss; Alonso ÁlvareZ, R., El monasterio cisterciense de Santa María de Cañas (La Rioja). Arquitectura gótica, patrocinio aristocrático y protección real, Instituto de Estudios Riojanos, Logroño, 2004, p. 33; BAURY, G., Les religieuses...; «Sainteté...»;

${ }^{78}$ SAlaZAR Y CASTRO, L., Historia... Vol. 2, Libro XVI, pp. 62-63.
} 
hija póstuma de don Lope y doña Aldonza ${ }^{79}$, que nació en el monasterio de Cañas y que vivió 92 años, siendo abadesa entre 1225 y $1262^{80}$.

Pudo ser una confusión debida a que las lagunas se reelaboraron para suplir la falta de información ${ }^{81}$, o bien el resultado de una intención, pues interesaba más que doña Urraca fuese hija de don Lope y doña Aldonza y no su nieta - aun teniendo en cuenta la importancia histórica de su padre, Diego López de Haro- por un hecho de prestigio y de cercanía sanguínea y cronológica a la fundación ${ }^{82}$. Por otro lado, la estrecha relación que la cuarta abadesa tuvo con su tía doña Urraca de Vileña, y que se manifiesta en la historia encargada por la abadesa burgalesa Ana de Guzmán que presentaremos a continuación ${ }^{83}$, puede estar detrás de la semejanza de los sepulcros de ambas religiosas, a lo que se añade la relativa proximidad geográfica de ambos monasterios ${ }^{84}$. Fray Pedro Ponce de León, llega incluso a afirmar en su relato de Vileña que Urraca Díaz «murió y mandóse enterrar con su tía la reyna doña Urracha López en este monasterio de Vileña» ${ }^{85}$, noticia que resulta dudosa. Doña Urraca de Cañas es además conocida por haberse considerado tradicionalmente como beata debido al recuerdo interno de las grandes virtudes que poseyó ${ }^{86}$ y que compartió con otras damas de su familia como su abuela doña Aldonza ${ }^{87}$, su tía doña Mencía y su hermana doña María ${ }^{88}$. Todo ello

\footnotetext{
${ }^{79}$ Así lo indica la noticia del Cartulario: «apenas murió el conde se hizo religiosa, en dicho convento de Cañas, en compañía de una hija, llamada también Urraca, que fue después abadesa allí, y muy célebre así por las obras que hizo en él, como por grande virtud». AHN, Clero, Códices, L. 1168.

${ }^{80}$ Versiones recogidas por MARCOS PASCUAL, E., Historia..., pp. 95-97 y 140-146; ABAD LEÓn, F., Real..., p. 97. Sobre la longevidad y la santidad como elemento de prestigio: BAURY, G., «Sainteté...», pp. 156 y 179.

${ }^{81}$ BAURY, G., «Sainteté...», p. 153.

${ }^{82}$ Aurell, J., «Memoria dinástica...», p. 326.

${ }^{83}$ BNE, Ms. 13127, ff.182r-188 r. Esta abadesa ejerció entre 1551 y 1579, cuando ya figura María Carrillo de Albornoz como superiora de la comunidad. CADIÑANOS BARDECI, I., El Monasterio..., p. 45.

${ }^{84}$ Sobre el sepulcro de doña Urraca de Vileña: CADIÑANOS BARDECI, I., El Monasterio..., p. 49. RUIZ MALDONADO, M., «Escultura funeraria del siglo XIII: los sepulcros de los López de Haro», Boletín del museo e instituto Camón Aznar, LXVI (1996), pp. 91-170, ha señalado la similitud estilística como rivalidad entre las abadías de Cañas y Vileña en torno a 1270, en BAURY, G., «Sainteté...», p. 155.

${ }^{85}$ BNE, Ms. 13127, f. 188 r.

${ }^{86}$ Entre ellas, destacan las de «humildad, desprendimiento, preocupación por sus monjas», señaladas por Marcos PASCUAL, E., Historia..., p. 141.

${ }^{87}$ La condesa ingresó en el monasterio de Cañas poco después de enviudar. SALAZAR Y CASTRO, L., Historia... Vol. 2, Libro XVI, p. 62; ABAD LEÓn, F., Real..., pp. 67-70; MARCOS PASCUAL, E. Historia..., p. 86.

${ }^{88}$ Doña María Díaz de Haro figura en tres ocasiones en la historia de la reina doña Urraca, siempre junto a su marido, Gonzalo Núñez de Lara, su hermana, Urraca Díaz, y su cuñado, Álvaro Núñez de Lara. Junto a su hermana, figura como mediadora del conflicto entre sus maridos y su hermano, Lope, reclamando la intervención de algunos abades: «en este tiempo doña Urracha Díez, muger del conde don Álvaro Núñez, y doña María Díez, muger de este don Gonzalo Núñez, que a la rasón estavan en Virviesca, que enbiaron a rogar al abbad don Diego de Oña y al abad don Domingo de Obarenes y al abbad don Gil de Buxedo y a otros santos monxes y los pusieran en paz». BNE, Ms. 13127, ff. 185 v y 187 r. Doña María figura como condesa y abadesa en GUTIÉRREZ PAJARES, Ma T., El monasterio..., pp. 26-27; AHN, Clero, Carp. 1731 (S. XIII), entre otras referencias. Figura como «señora» de San Andrés de Arroyo en un privilegio de Alfonso X concediendo la villa de Becerril al monasterio en 1255. AHNob, Frías, C. 432, Doc. 1, f. 3. Las señoras eran seglares pertenecientes a la familia fundadora, vinculadas a la gestión externa del monasterio, a modo de intermediarias. BAURY, G., Les religieuses..., en CAVERO DOMÍNGUEZ, G., «El monasterio...», p. 128; BANGO TORVISO, I., «Las pretensiones...», p. 229; REGLERO DE LA FUENTE, C. M., «Las "señoras" de las Huelgas de Burgos: infantas, monjas y encomenderas», e-Spania, 24 (2016). Véase también la nota 70.
} 
pudo propiciar la distorsión de su parentesco, idea formulada por García Turza para los centros monásticos plenomedievales: la «reformulación de la vida del santo» como forma de propaganda hacia el exterior ${ }^{89}$. Por último, Ghislain Baury ha demostrado que la santidad de doña Urraca fue una construcción posterior sobre la base del recuerdo de una mujer de grandes cualidades, debido tanto al aprecio que la comunidad monástica tuvo hacia la abadesa a lo largo de los siglos, como al vacío informativo, que llevó a presentarla como santa y como virgen a partir del siglo XVII, llegando la tradición hasta la actualidad ${ }^{90}$.

\section{LA INTERPRETACIÓN DEL PASADO INSTITUCIONAL: SAN VICENTE EL REAL DE SEGOVIA}

Los ejemplos anteriores definen memorias construidas a lo largo del tiempo en función de diversos estímulos y noticias aisladas, procedentes en muchos casos de la tradición oral, que se tenían de estas mujeres de notable resonancia histórica y espiritual. Sin embargo, en San Vicente el Real de Segovia encontramos dos ejemplos de documentación del pasado institucional del monasterio con un fin legitimador de su posición económica y política con respecto al clero secular. Ambos testimonios datan del siglo XVIII, y conciernen al pasado medieval en dos formas de preservación y recopilación más o menos fiel de la historia del monasterio como institución: escrita y oral, que se dotaron de argumentos de autoridad y quedaron recogidos en testimonios de acceso restringido ${ }^{91}$.

El primero de los textos, contenido en uno de los libros de contabilidad (1726-1728), es una curiosa evidencia del deseo de documentar, conservar y comprender una serie de epígrafes que se encontraban distribuidos por distintos puntos del monasterio ${ }^{92}$. Desconocemos la motivación que llevó al escritor anónimo, o escritora, pues pudo encargarse de ello una monja de la comunidad ${ }^{93}$, a recopilar las inscripciones del monasterio. Tendremos para ello que preguntarnos qué epígrafes se recogen, de qué partes se compone su análisis y qué se enfatiza a la hora de presentar y explicar su contenido. Según han indicado Casas y Palomo en su completo trabajo sobre la historia y el proceso constructivo de San Vicente el Real de Segovia, Quadrado y el Marqués de Lozoya propusieron a Casimiro Pérez, capellán del monasterio, como autor de uno de los calcos de la inscripción ${ }^{94}$. El texto transcribe sorprendentemente solo tres epígrafes ubicados en el interior de la clausura, frente a los siete

\footnotetext{
${ }^{89}$ GARCÍA TURZA, J., «Los monjes...», pp. 131 y ss.

${ }^{90}$ BAURY, G., «Sainteté...», pp. 153-156, 160 y 176-179.

${ }^{91}$ Desde la Plena Edad Media, «los modelos utilizados para la construcción de la memoria (...) están en constante transformación, al igual que los escenarios políticos, económicos y religiosos en los que se encuentra cada monasterio», y las respuestas dadas varían en cada monasterio, aunque puedan partir de una base común. GARCía TURZA, J., «Los monjes...», p. 125.

92 AHN, Clero, L. 12062, ff. 1r y 1v. El texto se recoge en el Apéndice documental, Doc. 3.

${ }^{93}$ Sobre la autoría en el monacato femenino: CABRÉ I PAIRET, M., «De la leyenda...», pp. 54-56.

${ }^{94}$ Casas Castells, E., y Palomo FernándeZ, G., «Santa María...», Nota 54, p. 43.
} 
que documentaron Elena Casas y Gema Palomo ${ }^{95}$. Concretamente, el texto contiene los epitafios de doña Sancha en dos ocasiones ${ }^{96}$ y de doña Marquesa, e indica que el primero de ellos estaba ubicado en el patio del claustro, donde se encontraba Nuestra Señora de las Aguas, localización que podemos identificar con la que Casas y Palomo definieron como «junto a la escalera de bajada del coro, en el muro interno de la galería sur del claustro» ${ }^{97}$, mientras que la segunda estaba emplazada «a los pies del Santísimo Christo de la columna en la capilla de Nuestra Señora de la Concepción» ${ }^{98}$. ¿Por qué razón solo se recogieron estas dos inscripciones y una de ellas dos veces? Podríamos pensar en alguna reforma parcial que afectó a ambas y que obligó a transcribir y analizar el contenido de los epígrafes con el fin de que no se perdiese, constituyendo así otra forma de preservar la memoria las abadesas y monjas del monasterio, o bien por la extrañeza que sugería la información que transmitían, especialmente su terminología, y que hizo que la comunidad quisiera darle una explicación. Esto justificaría lo llamativo del método epigráfico seguido por el autor, muy similar al actual: estudio de caracteres externos — forma, ubicación, estado, tipo de escritura-, estudio de caracteres internos - transcripción, lectura explicada, traducción y estudio terminológico e histórico-. Sin embargo, en las transcripciones, que no siempre son fieles, se utiliza un latín muy distorsionado, lo que nos lleva a considerar que el autor no conocía bien la escritura gótica, y además se añaden elementos en la traducción que no contiene el texto original. Que el documento indique dónde se hallaban las inscripciones proporciona una información muy valiosa sobre elementos que se encuentran descontextualizados, o bien sobre la ubicación que tenían en el siglo XVIII, que podía no ser la original debido a las constantes reformas que sufrió este monasterio ${ }^{99}$. Por último, es interesante que ofrezca una explicación terminológica, aunque a menudo resulte inadecuada en función del conocimiento que tenemos en el presente $^{100}$.

En el epígrafe de doña Sancha nos percatamos de algunas posibles incorrecciones, tales como la identificación de la cifra III de la línea 4, que seguramente no corresponda a Sancho Benito, sino a las III kalendas de mayo, es decir, el día 30 de dicho mes, al tiempo que es posible que este personaje no se trate de "don Sancho Benito", sino del "Señor. San Benito", es decir, que la lectura quedaría configurada de la siguiente manera: «uxor

\footnotetext{
${ }^{95}$ Ibidem, pp. 35-38 y 43, han indicado que los epígrafes están también transcritos en un pergamino que se conserva en el AMSV.

${ }^{96}$ CASAS CASTElls, E., y Palomo FernÁNDEZ, G., «Santa María...», Nota 58, p. 43, apuntan que se trata del mismo epígrafe reproducido dos veces, añadiendo que «el texto latino es idéntico, siendo ligeramente distinta la traducción».

${ }^{97}$ AHN, Clero, L. 12062, f. 1r. Sobre este epígrafe, remitimos al trabajo de CASAS CASTELLS, E., y PALOMO FERNÁNDEZ, G., «Santa María...», p. 38.

${ }^{98}$ AHN, Clero, L. 12062, f. 1r. El estudio de esta inscripción ha sido realizado por CASAS CASTELLS, E., y PALOMO FERNÁNDEZ, G., «Santa María...», p. 36.

${ }^{99}$ Sobre la evolución constructiva de San Vicente el Real: CASAS CASTELls, E., y PALOMO FernándeZ, G., «Santa María...», pp. 46-58.

${ }^{100} \mathrm{El} \mathrm{mismo}$ autor acepta su desconocimiento sobre ciertos temas: «Nota: Aunque la tradución no es rigurosa, pero puede dar luz para su caval versión, la que yo no puedo dar por la causa del mete y tibi y tal vez dixa: meum». AHN, Clero, L. 12062 f. 1v; nota citada por CASAS CASTELls, E., y PALOMO FERNÁNDEZ, G., «Santa María...», p. 44.
} 
D(o)m(i)ni. Sancii Benedicti, III K(a)l(enda)s / (5) may» ${ }^{101}$, y la traducción podría interpretarse como «esposa del Señor. San Benito, 3 kalendas de mayo», lo cual pude deberse a que nos encontramos en un monasterio que sigue la Regla de San Benito, tal como sucede en el Císter, o bien a que falleció un día en el que se celebraba alguna memoria o festividad relacionada con San Benito, suponiendo que no se trata del nombre Sancii, sino del término Sancti ${ }^{102}$. Por otro lado, el autor añade una nota a la traducción que no está presente en el epígrafe: «Sancha siguió tu pisada con mucho anelo, o Rey Christo» ${ }^{103}$. Por su parte, el ejemplo del obituario de la abadesa Marquesa Adámez resulta curioso por dos razones: la explicación terminológica del nombre de «Marquesa» y la datación:

Los términos donna Marquesa se usaban en los pasados siglos, no reparando mucho en omitir el nombre con tal que pusieran el título. Comismo digo de el término Genosa, lo usavan con la grandeza, y hasí se encuentra varias vozes en la istoria antigua: genosos homes: que oy equivale a Grande de España ${ }^{104}$.

Sin embargo, podemos suponer que la abadesa en cuestión no era probablemente una marquesa por nacimiento o matrimonio, sino que se llamaba Marquesa, al tiempo que la inscripción original contiene un error del ordinator que quedó igualmente reflejado en el texto analizado, si bien el autor no se percató de ello: esta abadesa no murió en $1089^{105}$, sino en 1289, pues la documentación evidencia que desempeñó el cargo abacial desde 1282 hasta dicha fecha ${ }^{106}$.

El segundo ejemplo, también del siglo XVIII, podría haberse escrito en un documento suelto que se copió en el Libro Becerro con el fin de conservarlo, controlarlo y dejar constancia tanto del pleito al que daba respuesta como de la historia del monasterio para consultas internas posteriores. Al contrario que el anterior, tiene una intencionalidad político-económica clara, que además expresó su autor de forma evidente tras una disputa con la iglesia de San Lorenzo, cuyo párroco insistía en que el monasterio de San Vicente dependía económicamente de dicha institución y, por tanto, debía percibir los diezmos correspondientes al monasterio. La comunidad y su mayordomo elaboraron en consecuencia una historia del monasterio que trató de justificar su antigüedad remota como parroquia independiente, de manera que «esta immemorialidad debe tener más fuerza quando no se puede ni suponer, ni probar el cura de San Lorenzo que la parroquia de San Vicente estuvo en tiempo alguno en

\footnotetext{
${ }^{101}$ La transcripción del epígrafe se encuentra en la nota 179 de este artículo.

102 Es curiosa la explicación que ofrece el autor sobre «Sancho Benito III»: «Adviértase que al principio dice Sancia, y después Dona Sancia, por ser ya muger de don Sancho, y Ferbado no tiene don, por lo que colige que Sancha era hija de algún caballero vascongado y casó con algún rey de Navarra o señor de Vizcaya. (...) Se infiere que aunque Sancha y su padre Ferbado Escacha no fuesen príncipes o reyes, pudieron ser de la primera nobleza, quando casó con uno que sin duda fue rey, como consta de el título Sancho III, pues solo los reyes se llaman con nombre numerado». AHN, Clero, L. 12062, f. 1r.

${ }^{103}$ AHN, Clero, L. 12062, f. 1r.

${ }^{104}$ AHN, Clero, L. 12062, f. $1 \mathrm{r}$.

105 Casas Castells, E., y Palomo Fernández, G., «Santa María...», Nota 57, p. 43, comentan que Quadrado y el Marqués de Lozoya pusieron ya en duda dicha datación, señalando que pudo deberse a una omisión de las dos CC por considerarlo obvio.

${ }^{106}$ AHN, Clero, Carp. 1965, Docs. 13, 14, 15 y 16; CASAS CASTELls, E., y PALOMO FernÁNDEZ, G., «Santa María...», p. 77.
} 
su distrito» ${ }^{107}$. Pero no solo es la intención lo que resulta más interesante de este testimonio, sino la forma en que el autor, vinculado al monasterio, defiende y justifica sus ideas, empleando elementos de autoridad como citas bibliográficas de prestigiosos autores que podrían resultar válidas académicamente incluso en la actualidad ${ }^{108}$. Llega a mencionar restos materiales como pilas bautismales a modo de evidencia de la funcionalidad del monasterio como parroquia, redactando así un trabajo que integraba fuentes escritas y arqueológicas. Esta argumentación, además, muestra que dicha elaboración estuvo condicionada por la ausencia de fuentes documentales, «principalmente por averse quemado este archibo» ${ }^{109}$. Conocemos dos importantes incendios en este monasterio, uno de ellos a inicios del siglo XIV y otro en 1616$1617^{110}$, generando un grave problema por la pérdida de privilegios, que constituyó un inconveniente a la hora de recurrir a la memoria del monasterio, pero por otro lado permitió expresarla según los intereses buscados.

Ante todo, el relato busca afirmar la antigüedad del monasterio como centro religioso, con el fin de justificar su posición, pero también como forma de dotar de autoridad religiosa su presencia recurriendo a un pasado inmemorial ${ }^{111}$, algo que ya fue buscado por todos los cenobios desde la Plena Edad Media ${ }^{112}$. Ambos textos tienen algunas características en común, tales como un autor de poca relevancia, por lo que podemos suponer que fueron encargados internamente por las abadesas, mayordomos y/o capellanes, pues los oficios masculinos externos a la comunidad monástica se hacían cargo, en muchas ocasiones en nombre de la propia superiora, de los asuntos externos del monasterio ${ }^{113}$.

\section{LA EXALTACIÓN DEL PASADO HEROICO: SANTA MARÍA DE VILEÑA}

Mientras en la Edad Media el medio de transmisión más común fue el oral ${ }^{114}$, durante la Edad Moderna se generalizó el soporte escrito, más estable para su preservación en líneas generales $^{115}$. En el monasterio de Vileña encontramos un ejemplo representativo, fechado

\footnotetext{
${ }^{107}$ AHN, Clero, L. 11974, s/f. (Libro Becerro).

108 Tal como se observa en la referencia: «Lo mismo dice el P. M. Flórez en su Historia Sagrada / Historia de Segovia / trat. 22, cap. 3, pág. 82, por estas palabras reconoce Mondéjar por iglesias antiguas del tiempo de los moros (...)». AHN, Clero, L. 11974, s/f. (Libro Becerro).

${ }^{109}$ AHN, Clero, L. 11974, s/f. (Libro Becerro).

110 Casas Castells, E., y Palomo Fernández, G., «Santa María...», pp. 35 y 45. Los documentos al respecto han sido publicados por las mismas autoras, pp. 86-87, Doc. 7.

111 AHN, Clero, L. 11974, s/f. (Libro Becerro). Véase Apéndice documental, Doc. 2.

112 GARCía TURZA, J., «Los monjes...», p. 126.

${ }^{113}$ Es un rasgo que se observa en todas las épocas, dependiendo de la coyuntura externa y de la personalidad gubernativa de la abadesa. Son dos ejemplos de San Andrés de Arroyo los de María Núñez y su delegación en su capellán, Domingo Abad de Prádanos (1303-1321), y de Urraca Pérez de Rojas, cuyo abadiato fue más activo (1326-1352). PENAS GonZÁLEZ, E., «Los ecos...» (En prensa). Sobre los oficiales externos: BAURY, G., Les religieuses..., pp. 261 y ss; FORTÚN y PÉREZ DE CIRIZA, L. J., «Cotidianidad y tensiones internas en las comunidades cistercienses medievales», en El monasterio medieval como célula social y espacio de convivencia, GARcía de CoRTÁzAR y RuIZ dE AguiRre, J. A., y TEJA CASUso, R. (coords.), Fundación Santa María la Real, Aguilar de Campoo, 2018, pp. 132-176; CoElHo, M. F., Expresiones..., pp. 131-176.

${ }^{114}$ DacostA, A., «El noble...», p. 257.

115 MARIMÓN LlORCA, C., «"La memoria...», pp. 150-152.
} 
entre 1544 y 1579 , generado con otra finalidad para la que era necesario conocer el pasado fundacional: la cohesión interna de la comunidad y del monasterio como espacio de identidad en un contexto de reforma y tendencia a la uniformidad religiosa ${ }^{116}$. Se trata de un relato sobre la vida de la reina Urraca López de Haro, fundadora de Vileña, cuya elaboración fue encargada por la abadesa Ana de Guzmán a Fray Pedro Ponce de León (1504-1584) ${ }^{117}$, monje del monasterio benedictino de Oña, también en Burgos, dedicado a la educación de sordos y, por tanto, un intelectual de referencia en su momento ${ }^{118}$. En este caso es interesante analizar no solo el contenido y sus variaciones con respecto a una historia que conocemos con bastante certeza, sino las omisiones ${ }^{119}$. Una de las características internas del texto, que figura en un traslado escrito a mano e incluido en un libro recopilatorio de la BNE, es la manera que el autor tuvo de enfocar su contenido, que configura la personalidad de las mujeres de la familia Haro a partir de las hazañas militares de sus padres, maridos y hermanos ${ }^{120}$. De doña Urraca se mencionan cualidades como la hermosura y la sabiduría ${ }^{121}$, si bien no se la presenta como una mujer pía, prudente y devota, virtudes que se trataron de resaltar en la época, sino como una mujer manipuladora y capaz de controlar a su marido, Fernando II de León, volviéndolo contra su hijo, el futuro Alfonso IX ${ }^{122}$. Este hecho destaca ante la costumbre en aquella época

${ }^{116}$ Destacamos el ejemplo de las monjas concepcionistas, fundadas en el siglo XVI «en un contexto de reforma religiosa y de construcción del Estado moderno que buscaba imponer en el panorama monástico femenino una política centralizadora, con voluntad clara de uniformar experiencias», JORNET BENITO, N., «La relación...», p. 44.

117 «Relación de quien fue la reyna doña Urracha López, fundadora del monasterio de Vileña, ordenada por el venerable padre fray Pedro Ponce de León, de gloriosa memoria, dirigida y escrita a la muy magnífica señora, mi señora, doña Ana de Guzmán, abbadesa muy digna del monasterio de Vileña». BNE, Ms. 13127, f. 182 r. Entre las motivaciones que llevaron a solicitar dicha redacción a fray Pedro Ponce de León, este indica que «Por ocupación que e tenido tan en breve hacer en relacçión lo que por V. M. fue mandado, la qual relaçión no ago a manera de historia, ni ordenada por capítulos y mui en breve que se pudiera deçir harto más que a bien que deçir solo sigo y quiero satisfacer a V. M., que quiere saver como generossa quien fue la reyna doña Urracha y en qué tiempo vibió y qual don Lope Díaz de Haro fue su padre, y qual don Fernando, rey de león, fue su marido, y quantos hijos tubo, y quien fue la señora que está enterrada en la sachristía, pudiendo decir de más antiguo sus antecessores». BNE, Ms. 13127, ff. 182.

118 Sobre este autor: GASCÓn RiCAO, A., y StORCH DE GRACIA Y ASEnsio, J. G., Fray Pedro ponce de León, el mito mediático: los mitos antiguos sobre la educación de los sordos, Centro de Estudios Ramón Areces, Madrid, 2006; PÉREZ DE URBel, J., «Cuna y linaje de Fray Pedro Ponce», Archivos Leoneses: revista de estudios y documentación de los Reinos Hispano-Occidentales, 55-56 (1974), pp. 317-322; NúÑEZ Angulo, B., y Gómez Monedero, J. A., «Fray Pedro Ponce de León: monje ilustre del monasterio de San Salvador de Oña», en Oña. Un milenio: Actas del Congreso Internacional sobre el Monasterio de Oña (1101-2011), SÁNCHEZ DOMINGO, R. (coord.), Fundación Milenario San Salvador de Oña, Burgos, 2012, pp. 592-599.

${ }^{119}$ Sobre la importancia de estas ausencias: QuintAnilla RASO, $\mathrm{M}^{\mathrm{a}} \mathrm{C}$., y CARCELlER CERVIÑO, M ${ }^{\mathrm{a}} \mathrm{P}$., «La construcción...», p. 271.

${ }^{120}$ Sobre esta forma de recordar a las mujeres: RODRÍGUEZ, A., «De damas poderosas. Poder, memoria e influencia en la Baja Edad Media», en Discurso, memoria y representación. La nobleza peninsular en la Baja Edad Media, Gobierno de Navarra, Estella, 2015, p. 316.

${ }^{121}$ Estas cualidades se asociaron a muchas reinas en las crónicas hasta la época de María de Molina. BECEIRO PITA, I., «La parentela regia femenina en los relatos cronísticos alfonsíes y bajomedievales», en Castilla y el mundo feudal. Homenaje al profesor Julio Valdeón, VAL VALDIVIESO, Ma I., y MARTíNEZ SOPENA, P. (dirs), Valladolid, Junta de Castilla y León, 2009, pp. 540-542.

${ }^{122}$ En el documento, en el que se trata de enmendar la figura de Diego López de Haro, se indica de la reina lo siguiente: «y casó el rey don Fernando terçera vez con doña Urracha López de Haro, fue muy hermosa, y savia, y hubo en el rey dos hijos, a don Sancho y a don Garçía, los quales el rey dotó y heredó. El rey quiso mucho a esta reyna, tanto que el ynfante don Alonso se descontentaba, y a esta causa la madrastra le 
de buscar en la historia del linaje y en los antepasados modelos morales ejemplares de comportamiento a seguir ${ }^{123}$, especialmente encontrándonos en un monasterio de una Orden en proceso de reforma durante el siglo $\mathrm{XVI}^{124}$, que tendería a presentar a su fundadora como cabeza de linaje monástico y protectora de la religiosidad ${ }^{125}$. Podría encontrarse tras ello una intencionalidad de perpetuar el protagonismo político de la institución por parte de la comunidad recurriendo a la memoria de la fundadora, pues, como ha señalado Isabel Beceiro, «el protagonismo de cónyuges, hijas y hermanas de los reyes es mucho mayor en el período comprendido entre los siglos $\mathrm{X}$ al XIII» ${ }^{126}$.

Sin embargo, al igual que muchos nobles fueron tomados como modelos a seguir por sus descendientes, también pudieron ser expuestos como antítesis de lo que era considerado adecuado $^{127}$. Aunque quizá trataron de plasmar alguna de estas visiones con el relato, la intención de Fray Pedro pudo ser simplemente presentar la historia fundacional de Vileña a la abadesa. Ante este hecho, y en un momento cercano a las reformas religiosas y al Concilio de Trento, cuando, en palabras de la RMA Rosaria Spreafico, «por todas partes se asistió a una nueva floración de santidad y mística» ${ }^{128}$, cabe preguntarnos por qué no resultó más interesante $\mathrm{y}$, ante todo, efectivo, realzar el valor espiritual de la reina doña Urraca como fundadora del monasterio, con el fin de afianzar la autoridad de un centro religioso que no tuvo una importancia primordial en el Císter castellano a pesar de su fundación real ${ }^{129}$.

En el discurso, que resulta muy prolijo en lo relativo a las hazañas militares de los miembros masculinos de los linajes implicados en el panorama político plenomedieval castellano $^{130}$, se realizan también determinadas omisiones que parecen ser intencionales, tanto a nivel interno como externo, ocultando a doña Urraca bajo las figuras de su hermano, Diego López de Haro, su padre, sus sobrinos y los Lara. Como ha señalado Ana Rodríguez para las

hiço algunos enojos, especial que trataba con el marido, que alsassen por el rey a don Sancho el maior de estos dos sus hijos, y para esto trató con sus hermano don Diego López de Haro, que tomase el pendón de don Sancho, que lebantan vos por su sobrino alsándole rey, y don Diego jamás consentió, sino que beniese el reyno al ynfante don Alonso, el quel se andava fuera de la graçia del padre». BNE, Ms. 13127, f. $185 \mathrm{r}$.

${ }^{123}$ BECEIRO PITA, I., «La memoria...», p. 124.

${ }^{124}$ RodríGUEZ GONZÁLEZ, J. I., «El Císter...», pp. 106-110.

125 Sobre esta cuestión: BECEIRO PITA, I., «La parentela...», pp. 539-540.

${ }^{126}$ BECEIRO PITA, I., «La parentela...», p. 532.

${ }^{127}$ Un ejemplo de dicha enseñanza es la que trató de difundir Pedro Fernández de Velasco a su descendencia en torno a 1540. BECEIRO PITA, I., «La memoria...», p. 126.

128 SPREAFICO, R., «El lugar de la mujer en la familia cisterciense», Cistercium, 213 (1998), p. 1041.

${ }^{129}$ Sobre la historia y la economía de Vileña, PÉREZ-EMBID WAMBA, J., «El Císter...», p. 772; CADIÑANOS Bardeci, I., El Monasterio...; Álvarez Padilla, J., Reina...; Baury, G., «Une économie du patronage aristocratique. Le temporel des moniales cisterciennes en Castille (XIIe-XIIIe siècles)», en Mundos medievales: espacios, sociedades y poder. Homenaje al profesor José Ángel García de Cortázar. Tomo II, Díez Herrera, C., y Solórzano TelecheA, J. A. (dirs.), Universidad de Cantabria, Santander, 2013, p. 1067-1079; BAURY, G., Les religieuses..., pp. 98, 219 y ss, 232 y 243 y ss.

${ }^{130}$ Algo que coincide con los relatos genealógicos medievales, y que ha sido señalado por DACOSTA, A., «El noble...», p. 272, es que «se desvela la construcción de discursos en términos de tensión y competencia» entre nobles, y aunque en el caso estudiado ni quien encargó, ni quien reelaboró, ni a quien iba destinado era miembro de ninguno de los dos linajes implicados directamente, sí formaba parte de un linaje monástico. 
mujeres de la nobleza bajomedieval, estas damas «no eran consideradas de una forma independiente, sino subsidiaria de sus parientes masculinos» ${ }^{131}$, aunque era común que participasen de forma decisiva en «maniobras sociales en beneficio de la familia» ${ }^{132}$, ejerciendo un poder acorde a su rango en función de la época y las circunstancias ${ }^{133}$; dicha visión se mantenía vigente a inicios de la Edad Moderna. Entre las ausencias se encuentran las menciones a sus sobrinas María y Urraca Díaz, posteriores abadesas de Arroyo y Cañas, respectivamente, aunque no las asocia con este cargo $^{134}$, olvida quién era la madre de la reina Urraca $^{135}$, no menciona a su hermana doña Mencía como fundadora de San Andrés, y omite su primer matrimonio con Nuño Meléndez ${ }^{136}$, cuya hija, María Núñez, fundó el monasterio de Otero de las Dueñas, en León ${ }^{137}$.

Isabel Beceiro ha señalado en su estudio sobre los relatos genealógicos castellanos, los cuales pueden asemejarse en ciertos aspectos a este escrito, que este tipo de literatura se extendió entre los siglos XIV y XVI ${ }^{138}$, momento del «triunfo del linaje agnaticio, basado en la primacía de la primogenitura masculina y en la transmisión hereditaria e inalienable del grueso del patrimonio, merced al régimen de mayorazgo» ${ }^{139}$, lo que puede estar detrás de la ocultación de la figura de la reina tras los miembros masculinos de su entorno, habida cuenta de la notable importancia de su acción individual ${ }^{140}$.

De hecho, en todo el texto se percibe una preocupación por exaltar a los linajes implicados en la vida de doña Urraca, como si se intentase construir una narración del origen

\footnotetext{
${ }^{131}$ RodríGUEZ, A.: «De damas...», p. 316.

132 Ibidem, p. 319.

133 Ibidem, p. 323.
}

${ }^{134}$ A los días finales de Urraca Díaz de Haro se refiere de la siguiente manera: «y don Lope Díez vino a consolar a su hermana doña Urracha, que estava en Bureba, y dióla para su sustentamiento a Villayzán, que hera de su marido, que el rey le avía dado, y vivió esta señora en esta tierra, y murió y mandóse enterrar con su tía la reyna doña Urracha López en este monasterio de Vileña, en el cruçero hiço muchas cosas en ella, especialmente las claostras, fue muy rica de joias y mucho horo y plata». BNE, Ms. 13127, f. $188 \mathrm{r}$.

135 «Este don Lope Díez de Haro y la condesa doña Mencía Arias obieron a (...)». BNE, Ms. 13127, f. 182 v. La condesa Mencía Arias fue la primera esposa de Lope Díaz de Haro, si bien Urraca es hija de su segunda mujer, Aldonza Ruiz de Castro. MARCOS PASCUAL, E., Historia..., p. 88.

${ }^{136}$ AlONSO Álvarez, R., El monasterio..., p. 31; «Los promotores...», p. 673.

${ }^{137}$ BAURY, G., «Fundar...», p. 19; COELHO, M. F., Expresiones..., p. 38.

${ }^{138}$ Jaume Aurell ha indicado que la mitificación del origen del linaje comenzó en los siglos XI y XII, y que en la Península dicha costumbre se extendió entre los siglos XIV y XV, manteniéndose la tradición hasta el siglo XVI, momento en el que nos encontramos. AURELL, J., «Memoria dinástica...», pp. 303-304.

139 BECEIRO PITA, I., «La memoria...», p. 122.

${ }^{140}$ RodRígUEZ, A.: «De damas...», p. 323. En el momento de redacción de dicho relato la vieja nobleza, a la que pertenecían los linajes fundadores de Vileña, había desaparecido del panorama político, por lo que quizá se trató de buscar cierto grado de legitimidad en el recuerdo de los valores bélicos de «los grandes linajes del reino, que se remontan a los siglos XI-XIII», cuyas «hazañas guerreras se insertan en la colaboración con la monarquía para luchar contra el Islam hispano». BECEIRO PITA, I., «La memoria...», p. 133, en este caso exaltando el papel de los Haro y los Lara en las Navas de Tolosa y en la sucesión del Reino de Castilla. Todo ello enlaza con la recuperación del pasado como autoridad frente a los cambios. AURELL, J., «Memoria dinástica...», pp. 303 y 329. Georges Martin ha argumentado que, aunque se empleasen fuentes autorizadas, veraces y prestigiosas, «el historiador medieval modeló deliberadamente el pasado desde el presente, guiado por la voluntad de establecer entre este y aquel continuidades y semejanzas que contribuyesen a consolidar y moldear el poder a cuyo servicio estaba escribiendo». MARTIN, G., «Pasados...», p. 18. 
del monasterio que justificase un «sublinaje» derivado de la interacción de la Corona, los Haro y los Lara al estilo bajomedieval en una época no muy posterior, de manera que este tipo de narraciones «quizá no nos acerquen a los hechos históricos [...], pero sí a otros niveles de factualidad» ${ }^{141}$, en este caso buscados de manera indirecta por las monjas. Enlazando con los conceptos propuestos por Isabel Beceiro para los relatos genealógicos, entre los que realza, entre otros factores, su finalidad social y política, el sentimiento de parentesco y la legitimación del poder ${ }^{142}$, proponemos que este relato puede estar vinculado al deseo de legitimación de un monasterio a través de la memoria transversal de su fundadora. Da la impresión de que la propia comunidad monástica, con la ayuda de colaboradores destacados por su erudición y, por tanto, autoridad, trató de consolidar su posición en la Edad Moderna a través de los personajes implicados directa o indirectamente en su aparición, quizá como forma de buscar protección mediante el respeto a las grandes figuras plenomedievales en un momento de cambio.

E incluso podríamos considerar otra idea ya esbozada, partiendo de la percepción de la propia comunidad monástica ${ }^{143}$ : el surgimiento a partir de los Haro de un linaje monástico transmitido de generación en generación a lo largo de los siglos de actividad del cenobio. En este caso, sería este linaje interno el que trataría de legitimar y fortalecer su identidad en todos los ámbitos con el mejor conocimiento y exaltación de su figura fundadora, quien finalmente profesó en el monasterio pero no ocupó el cargo abacial ${ }^{144}$. Otra idea que enlaza con nuestra propuesta, relativa también a la nobleza bajomedieval, es que la estructura del linaje y su memoria traspasaba la parentela de sangre ${ }^{145}$, de manera que «el linaje aparecía [...] como una construcción mental» de gran fuerza como «realidad sociojurídica estructurada en torno al parentesco de sangre, aunque ampliado, por extensión, a otro tipo de relaciones, sustentadas en vínculos feudales y espirituales» ${ }^{146}$.

Interesa aquí destacar varios aspectos interrelacionados que vivieron los monasterios a partir del siglo XII y el Císter un siglo más tarde ${ }^{147}$ : el desarrollo de los núcleos urbanos condicionó su poder territorial ${ }^{148}$; el desplazamiento de los ejes políticos hacia el sur, junto al avance de la frontera, provocó la pérdida de su función geopolítica como servicio al rey ${ }^{149}$; a ello se unieron la menor atención del Papado y la crisis económica y espiritual ${ }^{150}$. Esta situación se observa también en la primera Edad Moderna: reformas sucesivas aplicadas a la vida

\footnotetext{
${ }^{141}$ Dacosta, A., Prieto Lasa, J. R., y Díaz de Durana, J. R.: «Introducción...», p. 12.

142 BECEIRO PITA, I., «La memoria...», p. 119.

${ }^{143} \mathrm{Al}$ profesar, cada monja adopta el monasterio como casa y a la comunidad como familia. PÉREZ MORERA, J., «Renunciar...», p. 162.

${ }^{144}$ CAVERo DomíngueZ, G., «El monasterio...», p. 105; BAURY, G., Les religieuses..., p. 155.

145 Sobre la identificación de linajes con determinados monasterios, e incluso la creación de «linajes artificiales» en torno a ellos: GRAÑA CID, Ma M., «Poder...», pp. 48-49 y 60.

${ }^{146}$ Quintanilla RASO, M ${ }^{\mathrm{a}}$ C., y CARCEller CERviÑo, Mª P., «La construcción...», p. 273.

${ }^{147}$ BANGO TORVISO, I., «Las pretensiones...», p. 238.

${ }^{148}$ GARCÍA TURZA, J., «Los monjes...», p. 141.

${ }^{149}$ GARCía TuRZA, J., «Los monjes...», p. 142; PENAS GONZÁlEZ, E., «Los ecos...», (en prensa).

${ }^{150}$ GARCÍA TURZA, J., «Los monjes...», p. 142.
} 
contemplativa $^{151}$; reformulación de las instituciones externas implicadas en la gestión de los monasterios ${ }^{152}$; crisis económica generalizada ${ }^{153}$, etc.

Otros dos hechos que resultan llamativos al analizar el contenido del relato es que el autor se desvía de su propósito, que intenta retomar sin éxito en varias ocasiones, mencionando que debe continuar con el argumento propuesto ${ }^{154}$, lo que puede reforzar la hipótesis informativa. Por último, realiza un apunte que refleja la importancia que concedían a la memoria de los antepasados ilustres: «pues de aquella sangre tan alta de Bernardo del Carpio, que el que oy vive verdaderamente verle es gran lástima, cómo se ba perdiendo su memoria» ${ }^{155}$.

\section{CONCLUSIÓN}

A través de este breve estudio hemos podido comprobar cómo algunos monasterios cistercienses femeninos emplearon su historia con distintos fines - internos y externos - dependiendo de las circunstancias a las que tuvieron que hacer frente en cada momento histórico, recordando a sus primeras abadesas y fundadoras como modelos a seguir o afianzando su posición hacia instituciones laicas y eclesiásticas durante la Edad Moderna, época de grandes cambios en la que su autoridad llegó a ser fuertemente cuestionada. De esta tarea se encargaron a menudo las propias abadesas y oficiales externos vinculados al monasterio, tal como sucedió en el caso de Ana de Guzmán en Vileña, o en los dos ejemplos de San

\footnotetext{
${ }^{151}$ Sobre las reformas en el Císter desde el siglo XV: RoDRíGUEZ GonZÁLEZ, J. I., «El Císter femenino...», p. 105 y ss; VVAA, «Martín de Vargas y el Císter: nacen los Bernardos», en Los monasterios de la Corona de Castilla en el reinado de los Reyes Católicos, 1475-1517: Las congregaciones de observancia, GARCÍA Oro, J., y PorTEla Silva, M J., (coords.), Liceo franciscano, Santiago de Compostela, 66.169-171 (2004), pp. 108-110; TOMÉ, J., «Martín de Vargas y las dificultades iniciales de la congregación cisterciense de Castilla», en Humanismo y Cister: Actas de I Congreso Nacional sobre Humanistas Españoles, RAFAEL de Pascual, F., Paniagua Pérez, J., Morocho Gayo, P., y Domínguez Domínguez, J. F. (coords.), Universidad de León, León, 1996, pp. 473-489; PASCUAL, F. R., «Nuevas aportaciones a los estudios sobre el Císter y proyectos para el futuro (Consideraciones a la sombra del Humanismo del siglo XVI)», Bulería, 2002.

${ }^{152}$ Sobre el patronato nobiliario y episcopal en el Císter durante la Edad Moderna: CERRATO MATEOS, F., El císter... Sobre la relación de los monasterios femeninos urbanos con la nobleza y el fin de su presencia en los enfrentamientos: GRAÑA CID, M M M., «Poder nobiliario y monacato femenino en el tránsito a la Edad Moderna (Córdoba, 1495-1550)», Cuadernos de Historia Moderna, 37 (2012), pp. 60-61.

153 RodríGUEz GONZÁLEZ, J. I., «El Císter femenino...», p. 105; CERRATO MATEOS, F., El císter... pp. 95110; Diago Hernando, M., "Monasterios...", pp. 819-836.

${ }^{154} \mathrm{El}$ autor menciona que su narración se ha desviado del propósito inicial: «Pues volviendo a mi propósito», BNE, Ms. 13127, f. 183 r, o «Todas las otras, ya que tengan alguna memoria, no bienen de manera que no aya que deçir de cada una. En fin, no puedo, que cansaré», BNE, Ms. 13127, f. 183 v. «Pues bolviendo al propósito», BNE, Ms. 13127, f. 183 v. «Esta señora doña Urracha, hija de don Diego López, muger del conde don Álbaro Núñez, que como se suçedió a delante se contará cómo passó la vatalla, no lo quento. (...) Tornemos a contar de la señora doña Urracha López», BNE, Ms. 13127, f. 184 v. Sobre el propósito escribe también al final de la relación: «pasaron grandes cosas que no se quentan aquí, pues no aclara lo que pretendo, que es ablar de los de Haro y quien fue la exselente reyna doña Urracha López, reyna de León, fundadora de esta cassa de Villeña (...), porque mi intençión no es de no haçer historia, ni lo que e escrito partirlo por capítulos, sino una vreve relaçión de lo que me fue mandado». BNE, Ms. 13127, f. $188 \mathrm{r}$.

${ }^{155}$ BNE, Ms. 13127, f. 183 v.
} 
Vicente de Segovia. Sin embargo, también pudo ser el recuerdo mantenido por la propia comunidad monástica lo que, generación tras generación, estuvo detrás de la preservación de una memoria con base real de las abadesas y fundadoras. Debemos considerar que cada comunidad constituye en sí misma una familia monástica, con una ascendencia cronológica semejante a un linaje y una estructura interna que persigue una finalidad común. Por ello, el recuerdo de las fundadoras como cabeza de linaje y ejemplo a seguir fue transmitido de generación en generación como garante de las costumbres de cada casa, que manifiestan una identidad particular dependiente de cada monasterio, con ciertos elementos mantenidos a lo largo del tiempo ${ }^{156}$ y transmitidos como forma de instruir y de defender la institución ${ }^{157}$.

En este trabajo hemos presentado manifestaciones muy diferentes a las que recurrió un grupo relativamente uniforme de monasterios en distintos momentos de su trayectoria. Resulta llamativo que, frente a las elaboraciones perfectamente justificadas de algunos de los monasterios cistercienses femeninos mencionados, nos encontremos en otros casos con la inexistencia «de una frontera clara entre la narración documentada y el relato legendario» ${ }^{158}$. Todos los ejemplos consisten en textos recogidos en volúmenes accesibles únicamente para la comunidad monástica y sus colaboradores más cercanos, por lo que no eran instrumentos de consulta pública y, por tanto, aptos para su difusión ${ }^{159}$. Por ello, podemos afirmar que los destinatarios eran o bien miembros de instituciones a las que se intentaba persuadir, o bien integrantes de la comunidad monástica a las que se trataba de instruir. Además, en tanto que atendemos a reelaboraciones y manifestaciones de la memoria del monasterio, estas aluden constantemente al pasado como forma de presentar su veracidad. En el ejemplo de Segovia concerniente a San Lorenzo, encontramos palabras derivadas de «tiempo» en cinco ocasiones, «inmemorial» en dos, «antigüedad» en cinco, «continuada» en una y «años» o «siglos» en dos. Por su parte, en el ejemplo de Vileña de la BNE, encontramos la palabra «tiempo» en nueve ocasiones, así como otros términos enfocados a recurrir al pasado como fuente de autoridad.

Aunque es importante conocer los mecanismos de elaboración de la memoria en los monasterios del Císter femenino a partir del pasado medieval, se debe constatar que no parten de una estrategia general establecida por la Orden, por lo que deben estudiarse atendiendo a cada caso particular, siendo muy variables incluso en un mismo monasterio a lo largo del tiempo. De hecho, ninguno de los monasterios estudiados dio protagonismo a su pasado cisterciense ni a su condición femenina a la hora de afirmarse como institución eclesiástica, aunque esta última pudo hacer necesario recurrir a herramientas de legitimación.

De esta manera, en los ejemplos de doña Mencía, doña Urraca de Cañas y doña Urraca de Vileña nos encontramos ante la memoria de damas cuya personalidad traspasó los

\footnotetext{
${ }^{156}$ Agradezco esta reflexión a la RMA Ma del Carmen Gordaliza, de San Andrés de Arroyo. Aspecto también señalado por SCHLOTHEUBER, E., «Educación...», p. 313.

${ }^{157}$ Esta instrucción, especialmente en materia religiosa, pudo quedar a cargo del personal masculino secular. SCHLOTHEUBER, E., «Educación...», pp. 311-312, 319-320, 325.

158 BECEIRO PITA, I., «La memoria...», p. 124.

${ }^{159}$ Ideas también indicadas por ESCALONA MONGE, J., «Cartularios...», p. 200.
} 
límites del monasterio como institución, mientras que en los ejemplos de San Vicente nos hallamos ante un caso de elaboración con fines judiciales de la memoria del monasterio, independientemente de los sujetos implicados en su constitución. Por otro lado, conviene señalar que los tres casos de identidades personales no poseen un patrón común, pues en Cañas y en Vileña se trató de registrar la memoria de las dos damas principales de su historia, respectivamente, dentro del linaje Haro, no solo a través de los escritos, sino también de otros elementos materiales como sus emblemas heráldicos, epígrafes o enterramientos ${ }^{160}$, por lo que ellas mismas pudieron encargarse de dejar una huella para la posteridad ${ }^{161}$, ligada a la fundación o dirección de sus abadías. Sin embargo, doña Mencía no plasmó su memoria de forma directa en San Andrés de Arroyo; fue enterrada allí como fundadora y abadesa, pero sin epitafio, sin alusión escrita o visual contemporánea a su linaje paterno o sin iconografía que ensalzase los acontecimientos de su vida, reflejo, por otro lado, de su humildad.

En conclusión, los monasterios estudiados trataron de reforzar la autoridad abacial frente a las reformas bajomedievales y el Concilio de Trento, tanto a nivel organizativo como litúrgico ${ }^{162}$, para lo que resaltaron el peso político de sus fundadores y la fuerte espiritualidad de sus primeras abadesas, expresando con ello un deseo de continuidad. Además, fue común que las monjas contasen con miembros del clero secular y regular para la elaboración de los discursos referentes a su pasado, como manera de dotarlos de autoridad a través del prestigio de algunos intelectuales. Por otro lado, San Vicente el Real hizo frente, en el siglo XVIII, a los cambios de mentalidad de la época, que favorecieron un registro exhaustivo de las evidencias de su pasado plenomedieval, preservándolas para ocasiones futuras, y a los conflictos que mantenía con instituciones laicas y eclesiásticas circundantes, especialmente tratándose del ámbito urbano. Esto permite comprender la visión del pasado que de manera directa o indirecta había llegado a monasterios en proceso de reforma, y conocer los mecanismos que utilizaron para dejar constancia de sus acciones, por ejemplo, los epígrafes -como forma de difundir y conservar determinadas noticias-, y escritos que, aunque cumpliesen una función en un presente determinado, se guardarían como testimonio de autoridad.

\footnotetext{
${ }^{160}$ Sobre el ámbito funerario en el Císter: BANGo ToRviso, I., FERnÁNDEZ GONZÁLEZ, E., y ARA GIL, C. J., «Un mundo para la eternidad», en Monjes y monasterios. El Císter en el medievo de Castilla y León, BANGO TORVISO, I. (coord.), Junta de Castilla y León, Valladolid, 1998, pp. 305-389.

${ }^{161}$ Sobre la representación, la memoria femenina y el patrocinio: RoDRíGUEZ, A., «De damas...», pp. 327329; sobre la memoria de estas damas y del linaje Haro, véase BAURY, G., Les religieuses..., pp. 75-90.

${ }^{162}$ Sobre la reforma del monacato femenino: Sesión XXV, De los Regulares y Monjas, de 1563. LÓPEZ DE Ayala, I. (ed.), El sacrosanto y ecuménico Concilio de Trento, Rosa y Bouret, París, 1857, pp. 360-391.
} 


\section{APÉNDICE DOCUMENTAL}

\section{Documento 1.}

¿1544 ${ }^{163}-1579^{164}$ ?, Monasterio de San Salvador de Oña - Monasterio de Santa María de Vileña, Burgos.

Historia de la reina Urraca López de Haro (1160-1230), viuda de Fernando II de León, escrita por fray Pedro Ponce de León por encargo de la abadesa de Vileña, doña Ana de Guzmán (1544-1579).

B. BNE, Ms. 13127, ff. 182-189.

Cit.- BAURY, G., «Sainteté...», p. 180, Nota 89.

F. $182 \mathrm{r}$

Relación de quien fue la reyna doña Urracha López, fundadora del monasterio de Vileña, ordenada por el venerable padre fray Pedro Ponce de León, de gloriosa memoria, dirigida y escrita a la muy magnífica señora, mi señora, doña Ana de Guzmán, abbadesa muy digna del monasterio de Vileña.

Por ocupación que e tenido tan en breve hacer en relacçión lo que por V. M. fue mandado, la qual relaçión no ago a manera de historia, ni ordenada por capítulos y mui en breve que se pudiera deçir harto más que a bien que deçir solo sigo y quiero satisfacer a V. M., que quiere saver como generossa quien fue la reyna doña Urracha y en qué tiempo vibió y qual don Lope Díaz de Haro fue su padre, y qual don Fernando, rey de león, fue su marido, y quantos hijos tubo, y quien fue la señora que está enterrada en la sachristía, pudiendo decir de más antiguo sus antecessores, tomaré desde don Ynigo, el que fue señor de Vizcaia, hubo un hijo que se llamó don Lope Díaz el Rubio, que cassó con doña Aldonza, hija del Señor de San Juan de Luz, tubieron un hijo que se llamó don Diego López el Blanco, fue mui primero y fue a la batalla de Palma con ochocientos cavalleros y otra mucha jente, y venido de ella casóse con doña María, hija del señor de Sant Juan del Pie de Puert, y ubo por hijo al conde don Lope. Este conde don Lope de Haro fue el primero que tomó el apellido de Haro. Casso con doña Mencía, hija del conde don Arias de Hella, en Navarra. Otros dicen que fue la Asturia y que heredó por parte de esta señora mucha tierra en su Asturias,

\footnotetext{
${ }^{163}$ Último año en el que figura Ana de Cartagena, predecesora de Ana de Guzmán, como abadesa de Vileña. CADIÑANOS BARDECI, I., El Monasterio..., p. 45.

${ }^{164}$ Año en el que ya figura María Carrillo de Albornoz, sucesora de Ana de Guzmán, como abadesa de Vileña. CADIÑANOS BARDECI, I., El Monasterio..., p. 45.
} 
y después que la trocó con el Rey de León, de quien se hiço vasallo, por Varacaldo y Somostro, y Guartago, junto en Vizcaya, que y sus encartaciones reconoçían rebeliones al rey de león, el conde don Lope Díaz de Haro fue mui [roto]

\section{F. 182 v}

Abledo, y siendo niño este rey don Alonsso fui ase real un castillo de Çorita, y hera su tutor el conde don Nuño de Lara, hermano de don Manrrique, que en una batalla mató Fernan Roiz de Castro, y consuta abia trataba muy mal a muchos eavalleres grandes del reyno, y a esta cerca que fue don Lope Díez contra la voluntad de don Nuño. Y suplicó don Lope al Rey, le diese una parte quel y su jente conbatiessen, y ganado el castillo despidiósse el conde don Lope en mucha gracia del rey. Y partido que fue del rey conde don Nuño de Lara, dixo al rey que no abía pagado al conde don Lope lo que abía servido, y que era bien que fuese y leal cançasse y con palabras y obras se lo agradeciesse mexor, y ansí lo hiço el rey, que le alcanzó y jamás pudo con el conde don Lope, que tomase rentas ni tierras del. Este don Lope Díez de Haro y la condesa doña Mencía Arias obieron a don Diego López de Haro y a doña Urracha, que fue reyna de León. Y a doña dicen que esta doña Mençía, que fue casada con don Ruy Gutiérrez de Castro, gran señor de Galiçia, Mençía, que murió donçella. Este don Diego López de Haro fue el que llamaron el Malo en la de Alarcos, digo, en la batalla de Alarcos: fue con el rey don Alonso y acojióse con la seña del rey. Y el rey fue desbaratado del Miramamolón de Marruecos, ençerróse este don Diego López en la Vilal de Alarcos y cercóle allí el Miramamolín, hiço pleitençia con él en que se diese la villa y que se fuese a poner en supreçión dentro de un año a Marruecos, y para ésto, que le diesse doce cavalleros el Miramamolín, y desde aquel día en adelante le llamaron don Diego López el Malo, asta que fue la gran batalla de las Navas de Tolosa, que vençió este don Alonso al Miramamolín de Marruecos y a su gran poder, tubo este don Diego López la delantera y híçolo muy de veliente y enmendó todo lo que perdió en la vatalla de Alarcos, y de allí adelante le llamaron don Diego López el Bueno, como le llamaban antes que le llamasen el Malo. Los señores de Vizcaya tienen la delantera en las vatallas, hablan por los hidalgos de Castilla. Los señores de Lara llevan la vandera delante de los reyes de Castilla, en este vatalla comoo en las otras lebavala delantera el conde don Diego, y el pendón el conde don Álbaro de Lara, hierno de Don Diego López este don Diego López casó con doña María Manrique de Lara, hija del conde don Nuño de Lara

\section{F. $183 r$}

quien fue tutor del emperador don Alonso, e Lara tubo por por hijos el conde don Álvaro de Lara y el conde don Gonzalo, y el conde don Fernando, que murió en tierra de moros. El conde don Álvaro y el conde don Gonzalo fueron hiernos de don Diego López, y don Diego, casado con su prima dona María. Los quales casamientos concertaron don Lope Díez de Haro y el conde don Nuño, cuando estubieron en la serca de Çorita, y murió don Lope de Arenas, bassallo de don Fernan Roiz de Castro, por la traiçión de Dominguillo. El 
rey don Alonso fue nieto del rey don Alonso, que ganó a Toledo, fue rey de Castilla y de León, tubo dos hijos en una hija del conde don Remón de Barçelona, sin las hijas que fueron a don Sancho el Deseado y a don Hernando. A don Sancho dio el reino de Castilla. Y a don Hernando el reyno de León. Dicen que fue esto por consenxo de don Almeric de Lara, conde, y del conde de Trastámara, don Fernan Roiz, que es de los de Castro, porque ubiesse desabenençia en el reino, más guiólo Dios Mexor, porque después de los días de este emperador don Alonso, el qual se coronó emperador en Santa María de Regla de León, antes que se caçase, y don Lope de Haro, conde de Navarra y señor de Vizcaya, fue quien el Papa Eugenio enbió al Arzobispo don Rodrigo y e este conde enbió para que asistiessen y cerimoniasen aquel coronamiento y assí nombrándolo el Papa quitó muchas cuestiones de muchos altos hombres que pretendían esta honrra, como hera don Pedro Núñez de Guzmán, don Ruy Ferrándes de Castro, don Rodrigo de Villalobos, el conde don Ponçe, don Martín de Almaçán, don Pedro Rodríguez Álbarez de las Asturias, conde de Noreña, don Osorio, hijo de uno de los jueses que fue entre el Cid, e los

\section{F. $183 \mathrm{v}$}

Ynfantes de Carrión. Y los condes de Lara y muchos hijos de los Ynfantes de Castilla y de León, que pretendían esta ympresa, y los condes de Lara y don Tello Núñez de Meneses, y don Ramiro Flóres, y don Ruy Gonçález Girón, y don Garçi Gutiérrez de Asza, y el conde don Almeric, que después fue llamado don Malrrique, y don Nuño Pérez de Lara, y el conde don Álbaro, y estos tres heran hermanos, hijos del conde don Garçía de Cavra, el hayo del ynfante don Sancho, los que mataron los moros en la batalla de Véles, en tiempo del padre de este don Sancho, el rey don Alonso el Sexto, que ganó a Toledo, y estaba allí Ruy Fernández el Calbo, con sus hijos cuatro. Estos heran de los de Castro, y estubieron otros muy grandes señores en esta coronación del rey, que no quento. Y aquí berán qué lástima es ber la banidad de este mundo, que de todos cuentos aquí estaban no ay casa de todas ellas si no es la de Astorga, que es la de Billalobos, que traen dos lobos desollados. Todas las otras, ya que tengan alguna memoria, no bienen de manera que no aya que deçir de cada una. En fin, no puedo, que cansaré. Y se sierto que de la generaçión de estos que tengo dicho dependen descendientes dellos que guardan ganado y caban (pues de aquella sangre tan alta de Bernardo del Carpio, que el que oy vive que verdaderamente verle es gran lástima, cómo se ba perdiendo su memoria). Este don Lop. Pues bolviendo al propósito, este don Lope, conde de Navarra y señor de Vizcaya, que tomó el primer apellido de los de Haro, porque aún que su agüelo y visagüelo se llamaron el uno el Rubio, y el otro el Blanco, su apellido hera Guerra y Orrozco por parte de su agüela. Murió este don Lope después, y suçedióle don Diego López, su hijo, al qual suçedió todo lo que tengo dicho de la de Alarcos. Y bolviendo a la batalla de las Nabas, venieron de reynos estranxeros muchas gentes, por servir a nuestro señor, contra los moros, y esta gente tomaron por caudillo a don Diego López de Haro, y en el puerto de Tolosa, más acá de Baessa, a do el Miramamolín abía puesto muchos moros para guardar el passo, que no pasassen, entró este don Diego López 
a su hijo, don Lope Díaz, y dos sobrinos suios, que le llamaban al uno Sancho Fernández Cañamero, [roto] Martín Núñez de Finoxossa, para que fuessen

\section{F. $184 \mathrm{r}$}

a tomar el puerto, y entre tanto vino un pastor, que algunos dixeron que fue ángel que mostró una passada arto probechossa a los deste exérçito. Y don Diego López, que fue con él y passó por el bado de Guadiana, él y toda la gente sin peligro, estando aparexadas las haçes de los moros, y de los espías. Y estando don Diego López para arremeter don Lope Díez de Haro, hijo maior de don Diego López de Haro, apeóse del cavallo y púsose de rodillas delante de su padre, don Diego López, y díxole: «pídoos por merçed como a padre y señor que pues el rey os dio la delantera que de tal manera agáis que no me llamen hijo de traidor, y acuérdese vos de la buena fama que perdísteis en la de Alarcos, y por Dios queredlo enmendar, y oy podéis hacer emienda a Dios, si en algún hierro secaystes». Don Diego, muy enoxado, bolbióse contra él y díxole llamara nos a vos hijo de la puta, mas no os llamaran hijo del traidor, y en de tal manera lo haré yo que sea honrra vuestra y escarmiento de los moros, mas yo ben oy de tal manera guardaréis a vuestro padre y señor en tal lugar. Entonces, don Lope se lebantó y le besó la mano, y don Diego López de Haro tomó consigo quinientos cavalleros muy buenos y a sus hijos: Lope Díaz, Pedro Díaz, y a primo, Yñigo de Mendoça y a Sancho Fernández y a Martín Muñoz, sus sobrinos, y hera su alférez don Pedro Aries de Toledo, tanbién hera su primo. Estos toledos heran de haçia Rioxa y no ay memoria de estos que heran montañesses, y como don Diego arremetió, passó todas las haçes de los moros, y tantos alaridos y tanto polvo abía, que Sancho Fernández, su sobrino, que andaba para guardar, y otros no le podían ber por dónde andaba, y Sancho Fernández, mirando el pendón de Maril, que traía oso pare [roto] hera el pendón [roto]

\section{F. 184 v}

lobos. Y ansí, don Diego, estando en gran prieça, y por quantos golpes le dieron jamás le pudieron mover de aquel lugar, antes enbió decir al rey don Alonso que fuese a tomar la tierra que Dios le daba, y anssí mobió el rey con los suios, y don Álbaro Núñez de Lara, que lebava la señal de del rey, hierno de don Diego López, casado con doña Urracha Díez, quando no alló lugar por do entrarse en el corral a donde estaban los moros con las cadenas en guarda del Miramamolín, cogió la rienda al cavallo y dále las espuelas, y saltó en el corral, y quando lo bieron los que le aguardaban, haçen lo mismo, y de esta manera fue el corral yronpido. Y después el rey dio a este don Álbaro la banda y cadena, no obstante que tanbién lo hiço el rey de Aragón y el de Navarra, y ansí tubo por armas vanda y cadenas. Esta señora doña Urracha, hija de don Diego López, muger del conde don Álbaro Núñez, que como se suçedió a delante se contará cómo passó la vatalla, no lo quento. Murieron en esta batalla más de duçientos mil moros y de christianos no más de siento y quinçe christianos. Ubo mui gran riquesa, mandó el rey don Alonso a don Diego López que repartiesse 
el despoxo, y repartiólo de esta manera: toda la riqueça que el rey y los sus naturales abíamos de aber llébenla los reyes de Aragón y de Navarra, y a vos, señor nuestro rey y señor doy yo la honrra de la vatalla y el aber que las gentes obieren tomado, sea para sí, y anssí supo don Diego guardar la honrra para su señor, beniendo de la guerra el rey de Castilla, y de León, estaban desabenidos sobre dos castillos que el rey de Castilla tenía, y bino el rey de León y dióselos el rey de Castilla por consierto que los deribasen, y el rey de León enbió a don Diego de Aro que los deribasse. Tornemos a contar de la señora doña Urracha López, hermana de don Diego López. El emperador don Alonso, entre otros hijos y hijas que tubo, tubo de la primera muxer a don Sancho y a don Hernando, y partiólos los reinos: a don Sancho, que llamaron el Deseado, dio a Castilla y murió moço. A don Fernando dio el reyno de León. [Roto] laval don Hernando cassó con hija del rey de

\section{F. $185 \mathrm{r}$}

Portugal y ubo al infante don Alonso, que después le sucedió. Y muerta su muger, doña Urracha, cassó segunda vez con doña Teresa, hija de don Nuño de Lara, el que fue tutor del rey don Alonso, sobrino de este rey don Fernando. Y esta doña Tereça Núñez, reyna de León, hera prima de la muger de don Diego López, doña María Malrrique. Murió esta reyna doña Tereça y casó el rey don Fernando terçera vez con doña Urracha López de Haro, fue muy hermosa, y savia, y hubo en el rey dos hijos, a don Sancho y a don Garçía, los quales el rey dotó y heredó. El rey quiso mucho a esta reyna, tanto que el ynfante don Alonso se descontentaba, y a esta causa la madrastra le hiço algunos enojos, especial que trataba con el marido, que alsassen por el rey a don Sancho el maior de estos dos sus hijos, y para esto trató con su hermano don Diego López de Haro que tomase el pendón de don Sancho, que lebantan vos por su sobrino alsándole rey, y don Diego jamás consentió, sino que beniese el reyno al ynfante don Alonso, el qual se andava fuera de la graçia del padre. Estava esta señora muy haçendada de rentas y castillos, que el rey su marido la dio en harras, y don Diego López no quiso dar el pendón del reyno de León a don Sancho Fernández, su sobrino, mas prometió a su hermana la reyna de la ayudar con todo su poder después de los días de su marido a la se defender y amparar las rentas y castillos que su marido el rey la abía dado. Y andando tiempo murió el rey don Hernando, en tiempo que el ynfante don Alonso, su hijo maior, andava desterrado por miedo de la madrastra. Y rey de Portugal, su agüelo, le ynbió a llamar [roto] dare el reyno, y estando para

\section{F. $185 \mathrm{v}$}

entrar en un batel para passar atraxo vino a nueba de la muerte de su padre el rey don Fernando, marido de la reyna doña Urracha, y casóse con la hija del rey don Alonso de Castilla, doña Berenguella. Y luego que entró en el reyno enbió a deçir a su madrastra que le diesse la tierra y castillos, y don Diego López le suplicó no desheredasse a su madrastra y a los ynfantes don Sancho y don Garçía, sus hermanos, y el rey don Alonso no le quiso oyr, y don Diego López se desnaturó dél y se apartó de ser su basallo, y fuése para Navarra 
y de Estella hiço muy reçia guerra al rey, y la reyna se salió del reyno a la tierra de los condes de Lara don Álvaro Núñez y don Gonçalo Núñez, que estaban casados con sus sobrinas, doña Urracha Díez y doña María Díez, y el conde don Diego estava casado con doña María Malrrique, hija del conde don Malrrique de Lara. Y no tubo hijo varón, y heredó el conde don Nuño su hermano el señorío y la tutoría del rey don Alonso, que entonces hera niño. Aquí no quento ninguna historia de las que toco; solo pretendo aclarar quién fue la reyna doña Urracha y los señores de Vizcaya. Y estubo en Amaya. Y en el tiempo el rey don Alonso de León enbióse a quexar a su suegro, el rey de Castilla, de don Diego López de Haro, que le haçía guerra, que le ayudase contra él, y el rey de Castilla se juntó con su hierno y fueron a pelear con don Diego a Navarra, y por el camino iban leganando la tierra. Ayudávanle a esta guerra sus hiernos los condes de Lara. Entretanto que los reyes iban, dexábale el rey sercado dos castillos de su madrastra, que se llamaban Monte Agudo y Aguilar, que los otros ya los abía ganado. Don Diego haçía la guerra e desde Estella en Navarra, y anssí los reyes le dieron vatalla, la qual fue muy herida de todas partes, porque abía de todas partes muchos cavalleros y muy buenos, y la vatalla estubo en peso que no se conozía cuales abían lo mexor, pero al cavo fue vençido don Diego, y de allí fuése para el rey moro de Valençia [roto] aracan que tan bien fue

\section{F. $186 r$}

rey de Aragón, su contrario. Y el rey don Sancho de Aragón vino sobre Valençia, y los moros dieron a don Diego López un lugar que defendiesse, y el rey de Aragón fue a conbatir aquel lugar y herieron al rey el cavallo y quedó el rey a pie, y entonces don Diego dióle un cavallo en que que subiesse, y assí escapó el rey, que no fue preso, y los moros tubiéronselo a mal porque no le prendió, que lo podía mui bien hacer, y él es dixo que no queçiesse Dios que él prendiesse al nieto del emperador don Alonso, su señor, natural, y por este enoxo que los moros obieron del, se fue luego para Marruecos a los moros, y anssí quedó don Alonso, rey de León, muy sosegado con su suegro, aunque duró poco. El conde don Álvaro y el conde don Gonçalo hiçiéronse amigos del rey de Castilla, los quales fueron por interçesión de la reyna doña Sancha de Aragón. Abía en aquellos tiempos en tierra de Bureba, la qual señorearon los condes de Lara, unos cavalleros ynfansones, entre los quales heran don Gutierre López de Fermosiella, Gutierre Rodríguez de Roxas, Fernán Royz de Soto, estos y otros servieron a la reyna doña Urracha y a los condes de Lara, cuios vasallos heran, en la villa de Busco, que agora es Busto, que en aquellos tiempos hera muy poblada y vien sercada, y tenía buena fortaleça. Estubo mucho tiempo allí viéndosele muerto ya los sus hijos, don Sancho y don Garçía, hermanos del rey don Alonso, y estando en aquella tierra sus sobrinas, que tanbién la acompañaron en los ynfortunios, según se contara, espeçialmente doña Urracha Díez, la reyna doña Urracha se retrayó con sus mugeres, que quisieron hacer a esta tierra de Bureba, y fundó el monasterio de Vileña, de la Orden del Sistel, y compróles rentas y muchos heredamientos, y allí se enterró. Dios, por su misericordia, la tenga en su gloria. Amén. Antes que [roto] don Diego López ynbió 


\section{F. $186 \mathrm{v}$}

a suplicar al rey de Aragón tubiesse por bien de abenirle con los reyes de Castilla y de león, y anssí se hiço, y entretanto que don Diego entrara en Marruecos con los moros sucedió que los castillos de Monteagudo y de Aguilar, que estaban por la reyna doña Urracha, los cuales dio a su hermano don Diego, túbolos sercados mucho tiempo el rey de León, y con una saeta mataron al alcaide de Monteagudo, y ansí se le ubo e[1] rey. El de Aguilar túbole sercado el rey más de siete años, llámase es[te] alcayde Marcos Gutiérrez, y en este tiempo faltóle la gente de hanbre, y enfermedades, y vino a tanto hambre que comieron los cavallos y gatos y ratones, y los cueros de las adargas y escudos, y como Marcos Gutiérrez ya quedó solo y estava para morir, tomó las llaves y baxó las puertas, y allí se echó con intençión de morir allí, antes que quebrantar el homenage que abía echo a don Diego, su señor. Y los que conbatían, como no bieron resistencia, subieron al castillo y vaxaron las puertas y toparon a[1] alcayde Marcos Gutiérres cassi sin sentido, y echáronle agua y tomáronle las llaves y abrieron el castillo y alimentáronle. Poco a poco volvió y lebáronle al rey, el qual le hiço muchas mercedes. Y en este tiempo vi[no] don Diego López de tierra de moros, y este alcayde fuése para el qual se hiço mucha honra, y un día, loando la balentía de este alcayde y su lealtad, dixo él, don Diego: «buen cavallero él y leal, mas yo mis castillos querría». Sintióse de esto tanto Marcos Gutiérrez, el qual hera natural de Ágreda, que le fue al rey de León y le suplicó que no quisiese andar sobre la tierra sin honrra por el castillo de Aguilar, que se le pedía don Diego, y el rey mandó que le diessen el castillo, y que inbiase a llamar a don Diego, que biniese por él, y anssí don Diego le inbió a desir que se le diese al rey don Alonso de León. Pasados algunos días murió este don Diego López, y está enterrado en San Millán de la Cogolla con su padre. Sucedióle en el señorío su hijo, don Lope Díez de Haro, tubo muchas cuistiones con sus cuñados los condes de Lara, don Álvaro y don Gonçalo, y con otro, don Hernando, que murió desterrado en tierra de moros, y las cuistiones fueron sobre quién se apoderaría de la crianza y gobernaçión del rey don Enrrique, el que mató la texa en Palencia, hijo del rey don Alonso de Castilla, hermano de la reyna doña Verenguella, muger de don Alonso, rey de León, entenado de la reyna doña Urracha López de Haro. Y este don Henrrique, quedó niño quando murió el rey don Alonso, su padre, en poder de doña Verenguella, reyna de León, que porque se allaron parientes su marido el rey de León y ella se apartaron. Esta fue madre del rey don Fernando el Santo, que ganó a Córdova y a Sevilla. Y esta doña Verenguella, hermana de don Enrrique, dio la tutoría del rey a don Álvaro Núñez de Lara, y entrególe al rey niño, y don Álvaro Núñez, contra la voluntad de muchos grandes, a los quales dixo que saliessen de la Corte, entre los cuales fue a don Lope Díaz de Haro, su cuñado, y a otros y a la reyna doña [roto]

\section{F. 187 r}

y perseguir con [roto] y essos nonbres, el conde don Álvaro la inbiava deçir peores palabras, y híçola muy malas obras y quitó las muchas rentas y muchos castillos, y don Lope Díez de Haro, biendo quam mal se hacía contra la reyna doña Verrenguella el conde don Álvaro, 
enbióselo a retraer, y anssí puso el conde don Álvaro al rey que le tomase la tierra y dende a poco tiempo supo el conde don Álvaro Núñez de Lara cómo don Lope Díez de Haro estava en Miranda de Ebro, y enibó a él a su hermano, el conde don Gonçalo, que tanbién hera cassado con su hermana doña María Díez, y dióle quatroçientos de cavallo y muchas gentes de pie para que fuese a él, y como lo supo don Lope Díez, enbióle a decir que no curase de tomar travaxo de yr a él, que él yría a le buscar. Y anssí salió don Lope de Haro con doçientos honbres de cavallo y dos mil hombres a pie. Y passó el río Hebro y fuese a topar con el conde don Gonçalo, el qual tomó un cerro y don Lope asentó en un llano, y en este tiempo doña Urracha Díez, muger del conde don Álvaro Núñez, y doña María Díez, muger de este don Gonzalo Núñez, que a la rasón estavan en Virviesca, que enbiaron a rogar al abbad don Diego de Oña y al abad don Domingo de Obarenes y al abbad don Gil de Buxedo y a otros santos monxes y los pusieran en paz. Y ansí se tornó el conde para el rey. Y don Lope se fue para Otilla, a donde estava la reyna, el qual lugar herade don Gonçalo Ruiz Gaión y sus hermanos y don Suer Téllez de Meneçes y don Alonso Télles de Menese, su hermano, y Ruy Gonçáles de Orbanexa y sus hermanos y Garçi Fernández de Villamayor, y Guillén Pérez de Guzmán, y Joan Pérez de Guzmán, y don Guillén Malrrique, suegro de este Joan Pérez de Gusmán, todos estavan juntos con sus gentes para reçistir el poder grande de don Álvaro Núñez de Lara con traer a su mando al rey, que hera niño. Y asta aquí le subió la fortuna todo lo que pudo, porque estando el rey en Palencia jugando a la pelota con otros niños, cayó una texa y dio al rey en la caveça, y murió. Y quedó don Álvaro muy sin favor, y bino don Fernando, el que fue santo, hixo de esta reyna y del rey de León, a reynar, y les hiço guerra, ca les tomó a Lerma y a Miñón [roto]

\section{F. $187 \mathrm{v}$}

la santa [roto] don Fernando estava en Castrogeriz. Y el conde don Gonçalo fuese a Vevilla, y el conde don Álvaro fuese a Crezuelo, y de todas estas partes hacían muy cruda guerra el rey, y el rey de León enbió al obispo de Obiedo, y que les ganaría tregua de el conde para que el rey anduviese seguro por su reyno, y entonçes la reyna doña Verenguella encomençó a llorar y deçir cómo el rey de León, mi marido, quiere ganar tregua del vasallo para que ante, seguió el su rey y señor por su reyno, y los que estavan allí no lo pudieron sufrir y adreçáronse y salen de Palençia y bánse para Herreçuelo, a do estava don Álvaro Núñez, y el conde bió venir las gentes, sale a ellos con los suios y don Ruy Gonçález Girón y don Ramiro Flórez heran cavalleros mançebos, y fueron delante por se probar en harmas, fuerças, y llegando la jente del rey salió el conde don Álvaro Núñez a ellos y fue la vatalla muy herida, y un cavallero que se llamava Joan Gonçález de Yzero, natural de Hosma, aremetió contra el conde don Álvaro y diole un enquentro por el lado que dio con el del cavallo en el suelo, y unos por él prender y otros por él socorrer, ubo gran vatalla. Al cavo el conde fue preso, y con él quinse cavalleros de los mexores, y los otros ençerráronse en el castillo y diéronles a don Roy Gonçález Girón y a Ramiro Gómez de Guzmán, porque no los conbatiessen, lebaron al conde don Álvaro delante de la reyna doña Verenguella y a su hijo el rey, y ubo tantos que rogaron por don Álvaro, que el rey se iço pleiteçía y conçierto 
con el que le soltaría, con condiçión que entregase los castillos que abía tomado, y soltáronle entretanto sobre su palabra, y andávase en el palaçio y después diéronle a don Gonçalo Girón y llebóle a Otilla, y allí estubo asta que fue entregado el rey de los castillos, y después que don Álvaro Núñez salió de la priçión, fuese a Baldenebro, una legua de Medina de Rioseco, y de allí hiço guerra al rey, y el conde don Fernando, su hermano, fuese a poner en la merçed del rey y híçole el rey mucha honrra, pero después se perdió otra vez, y el rey le tomó a Villahizán y se la dio a don Lope Diéz de Haro, y caió el rey malo en Castroxeriz y enbió al ynfante don Alonso, su hermano, que fuese a tomar a Paredes y a Beçerril, y deribó los castillos. Y el conde alçóse en [roto] y tubiéronle [roto]

\section{F. $188 \mathrm{r}$}

en salvo fuera del reyno, y dexó la mujer y los hijos encomendados al rey, y él fuese a Marruecos y híçose vasallo del Miramamolín, y allí murió. Y el conde don Álvaro, después que pasaron grandes cosas que no se quentan aquí, pues no aclara lo que pretendo, que es ablar de los de Haro y quien fue la exselente reyna doña Urracha López, reyna de León, fundadora de esta cassa de Villeña, y de doña Urracha Díez, mujer del conde don Álvaro Núñez de Lara, el que fue mui gran señor, el y sus hermanos en estos reynos, y alcavo se juntaron el señorío de Lara y de Vizcaya por casamientos, y quién es el verdadero señor de estas tierras, y cómo los hubo el rey de Castilla, y otras cossas del prinçipio de los condes de Lara no lo contaré porque mi intençión no es de no haçer historia, ni lo que e escrito partirlo por capítulos, sino una vreve relaçión de lo que me fue mandado. Pues suçedió que el conde don Álvaro Núñez, estando en Castroverde, que es en Campos, le vino una enfermedad de perleçía, una de las espeçies que llaman «hipostaron», y estubo con ella siete meses, y murió tan pobre que no ubo con qué le llebar a enterrar a Uclés, a do se mandó enterrar, y savido por la noble reyna doña Verenguella, no mirando los desserviçios que le hiço, mandó dar todo lo necessario para le llebar a enterrar, y enbióle un paño muy rico de horo para cobrir su cuerpo sobre el ataúd, y don Lope Díez vino a consolar a su hermana doña Urracha, que estava en Bureba, y dióla para su sustentamiento a Villayzán, que hera de su marido, que el rey le avía dado, y vivió esta señora en esta tierra, y murió y mandóse enterrar con su tía la reyna doña Urracha López en este monasterio de Vileña, en el cruçero hiço muchas cosas en ella, especialmente las claostras, fue muy rica de joias y mucho horo y plata. De la tía y la sobrina y de otras personas, pero los ingleçes se lo robaron, y dos o tres veçes los navarros. Antes de estos robos passó por ay el rey don Alonso, que traya guerra contra don Joan Núñez de Lara, señor de Vizcaya, y hiço gran acatamiento a esta señora reyna y confirmóle sus prebilexios y híçole otras grandes merçedes.

\section{Documento 2.}

S. XVIII, Monasterio de San Vicente el Real, Segovia. 
Justificación de la antigüedad del monasterio cisterciense de San Vicente de Segovia frente a las pretensiones del párroco de San Lorenzo de someterlo a su jurisdicción.

B. AHN, Clero, L. 11974, s/f.

Cit.- CASAs CAStells, E., Y PAlOMO FernándeZ, G., «Santa María...», Nota 24, p. 42.

Orijen y principio del curato e iglesia parroquial de San Vicente Mártir, que desde el siglo doce habitan monjas cistercienses, aviendo antes sido monjas negras, que el vulgo llama benedictinas. La iglesia parroquial de San Vicente, unida y anexada a esta comunidad de San Vicente desde su primera fundación para alimentos de ella, es antiquísima, según Colmenares al cap. 6. Por ser tanta su antigüedad, y principalmente por averse quemado este archibo, como consta de el privilegio de las quartillas, no se sabe, ni es fácil de saber, quándo se fundó este templo, que ia habla Colmenares por los años de $306^{165}$. Pero se sabe que de immemorial es parroquia, y es una de las antiquísimas que tuvo Segobia en los tiempos que su principal población estuvo en este valle de Eresma. Así lo testifica el Marqués de Agrípoli o de Mondéjar ${ }^{166}$, natural de Segobia y de la familia de los Peraltas, en sus Disertaciones Eclesiásticas, Disertación Segunda, verbo Templos de Segovia, donde hablando de las iglesias que avía en este valle, asegura que todas eran parroquiales. Así las refiere sin acordarse de la de San Lorenzo: «San Marcos, San Blas, San Gil, Santiago y las dos que se dieron a la Religión» de los Premostenses, que después se llama Santa María de los Huertos, y a las monjas Bernardas, dedicada a San Vicente, en cuya atención permanezen entrambas con pilas bautismales. Lo mismo dice el P. M. Flórez ${ }^{167}$ en su Historia Sagrada, Historia de Segovia, Trat. 22, Cap. 3, pág. 82. Por estas palabras reconoce Mondéjar por iglesias antiguas del tiempo de los moros las de San Marcos, San Blas, San Gil, Santiago, San Pedro de los Picos, y las dos que se dieron a los Premostatenses y Religiosas Bernardas, que tienen la invocación de santa María de los Huertos y de San Vicente, conservándose con pilas bautismales en atención a lo que fueron. El M. Flórez, aunque pone algunos reparos sobre la antigüedad que les concede Mondéjar, no disputa a estas iglesias la parroquialidad immemorial y continuada, y se le puede decir que, conviniendo los autores que hablan de Segobia, que principiaron a mudar de habitación por los años de 464 de $\mathrm{J} \mathrm{Ch}^{\circ}$ los segobianos a la cumbre con que aí estan las iglesias, se las debe suponer fundadas por esos años. De lo dicho se infiere que este curado, o parroquia, es uno de los que habla

\footnotetext{
${ }^{165}$ Se refiere a Diego de Colmenares (1586-1651), concretamente a su obra Historia de la insigne ciudad de Segovia y compendio de las historias de Castilla, 1637, ed. Eduardo Baeza, Segovia, 1846.

${ }^{166}$ En referencia a Gaspar Ibáñez de Segovia (1628-1708), historiador y noble cuyo segundo enlace con María Gregoria de Mendoza, le otorgó el título de Marqués de Mondéjar. Sobre su vida y obra: GARCía LÓPEZ, A., «El novator Gaspar Ibáñez de Segovia y su Historia de la Casa de Mondéjar», Wad-al-Hayara: Revista de estudios de Guadalajara, 31-32 (2004-2005), pp. 45-102.

${ }^{167}$ Enrique Flórez (1702-1773) fue un fraile e historiador agustino cuya obra cumbre es España Sagrada, que el texto analizado confunde con Historia Sagrada. Esta obra comenzó su publicación en 1747 y se prolongó más allá de la muerte de su autor. SAGREDO FERNÁNDEZ, F., «Enrique Flórez (1702-1773) y su "España Sagrada"», en Homenaje a Don Agustín Millares Carlo, Confederación Española de Cajas de Ahorros, Las Palmas de Gran Canaria, 1975, pp. 517-535.
} 


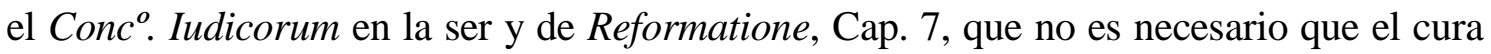
capellán sea el que tiene la cura habitual de esta parroquia, y que no dexa de ser parroquia aunque sea solo vicario. Infiérese lo $2^{\circ}$, que no exhibirá ni monumento, ni instrumento, ni testigos instruidos en estas antigüedades el cura de San Lorenzo, en que pruebe que su parroquia es más antigua que la de San Vicente Mártir, ni que esta está, ni estuvo, en territorio de aquella en tiempo alguno. Infiere lo tercero, que la parroquia de San Vicente no está erigida en virtud de privilegio alguno por mera voluntad de los señores obispos, que juzgaron oportuna su erección para proveer del pasto espiritual a los segobianos que habitaban en las proximidades de esta iglesia. Infiere lo quarto, que quatro hortelanos, sacrhistanes o semehantes personas no son personas aptas para deponer sobre distritos de una parrochia que acaso se fundó en el siglo quarto de la Iglesia; mayormente quedo de los tiempos antiguos no se halla razón alguna de tales distritos en la secretaría obispal, ni en otra parte. Para defender la propiedad de este curato y parrochia con territorio separado contra las oposiciones del cura de San Lorenzo, basta a esta comunidad el probar la immemorialidad continuada de parrochia con los testigos y Autores arriba dichos, los libros de bautisimo y matrimonios sin dependencia ni del cura de San Lorenzo, ni de otro alguno de Segobia, la pública voz y fama civil, y eclesiástico de tal parrochia, y para más esforzar estas razones convendrá leer y tener presentes las bulas del señor Benedicto XIV: Bula 16, Tom. 1, y la 33 del Tom. 2, donde los abogados hallaron esforzado y decididos casos prácticos del so virtud de la quema arriba enunciada. Y esta immemorialidad debe tener más fuerza quando no se puede ni suponer ni probar el cura de San Lorenzo que la parroquia de San Vicente estuvo en tiempo alguno en su distrito.

(Nota posterior, 1799): Con el motivo del pleito suscitado por el cura de San Lorenzo, a el que dio motivo el breve de S.S. sobre anular toda esención de diezmos, a el cura de San Vicente y Religiosas sobre su percepción, se presentaron para la prueva por parte deste cura de San Vicente varios papeles, como son los de aviso para que asista a los sorteos, para el repartimiento del pan de pobre de la ciudad [...].

\section{Documento 3.}

1726-1728, Monasterio de Santa María y San Vicente el Real, Segovia.

Reseña que recopila dos las inscripciones de la abadesa doña Marquesa Adámez y doña Sancha, presentes en el monasterio, inserta en uno de los libros de cuentas y salarios del monasterio.

B. AHN, Clero, L. 12062, ff. 1r y 1v.

Cit.- Casas Castells, E., Y PAlOMo FernándeZ, G., «Santa María...», Notas 54, 55, 56,57 y 58, p. 43.

Fol. 1r 
Epitafio que se halla a la entrada del coro alto de este monasterio:

Sesn. Note.: Sancia saguuit se totam rex tibi Christe: me te tibi vivit corpustumedus tegit iste: obiit d ${ }^{o}$ Sancia, filia Fenbadi Escacha, et user Domni Sancii Benedicti III. Nones maii, anno domini milesimo octagessimo secundo era milesima trecentesima vigesima ${ }^{168}$.

«Sancha se consagró con entera y firme resolución para ti o Rey Christo: este túmolo cubre a un cuerpo que, aunque de suyo es corrupble, empero vive, porque le has de resucitar. Murió doña Sancha, quien fue hija de Febado Escacha, y también mujer de don Sancho Benito III. Sancha siguió tu pisada con mucho anelo, o Rey Christo».

Este rótulo es el que se halla a los pies del Santísimo Christo de la columna en la capilla de Nuestra Señora de la concepción de este real monasterio de San Vicente, extramuros de la ciudad de Segovia:

Hic jacet Donna Marquesa, Abatisa istius monasterii, genosa, písida, et discreta Deo Patri Beate Marie, et omnibus santis, que obiit decimo kalendas julii anno Domini milesimo octisogesimo nonno ${ }^{169}$.

En romance: Aquí está sepultada la señora Marquesa, abadesa de este monaterio, noble, piadosísima, y escojida de Dios Padre, y de la vienaventurada María, y de todos los santos, la qual murió a 22 de junio del año de mil ochenta y nueve.

El rótulo original: avía en algunas letras para vasta esto para que puedan leerle con facilidad en lo sucesivo. Los términos donna Marquesa se usaban en los pasados siglos, no reparando mucho en omitir el nombre con tal que pusieran el título. Comismo dico de el término Genosa, lo usavan con la grandeza, y hasí se encuentra varias vozes en la istoria antigua:

${ }^{168}$ La transcripción y traducción que ofrecen CASAS CASTELls, E., Y PALOMO FernáNDEZ, G., «Santa María...», p. 38, es la siguiente:

«SANCIA : SAGIVIT : SE : TOTAM : REX : TIBI : XPE :

ME TE : TIBI : VIVIT : CORPUS : TUMULU : TEGIT : ISTE :

OBIIT : D(O)NA : SA(N)CIA : FILIA : TERBADI : ESCACHA : E

T UXOR : D(O)M(I)NI : SANCII : BENEDICTI : III : K(A)L(ENDA)S :

(5) MAY:

ANNO : D(OMINI : $\mathrm{M}: \mathrm{CC}: \mathrm{LXXX}: \mathrm{II}:$ ERA : $\mathrm{M}: \mathrm{CCC}: \mathrm{XX}$ »

«Sancha se consagró por entero a ti Rey Cristo. Este tumulo cubre un cuerpo que vive para ti. Murió doña Sancha, hija de Terbado Escacha y mujer de don Sancho Benito tercero el día 1 de mayo. Año del señor de 1282. Era 1320».

${ }^{169}$ La transcripción y traducción que ofrecen CASAS CASTELlS, E., y PALOMO FernáNDEZ, G., «Santa María...», p. 36, es la siguiente:

«IC : IAZET : DONNA : MARQUES

A : ABATISA : HISTI(US) : MONASTERII:

RELIGIOSA : GEN(ER)OSA : P(ER)ISIDA : E : DISCR

ETA : DEO : PATRIE BEATE MARIE

(5) $\quad \mathrm{E}: \mathrm{O}(\mathrm{M}) \mathrm{NIB}(\mathrm{US}): \mathrm{S}(\mathrm{AN}) \mathrm{C}(\mathrm{T}) \mathrm{IS}: \mathrm{QU}$ OBIIT : $\mathrm{X}^{\circ} \mathrm{CALENDAS}$ :

IULLI : ANNO : DOMINI : MILLESIMO : OC TUOGESIMO : NONNO»

«Aquí yace Doña Marquesa, abadesa de este monasterio religiosa, magnánima (noble), piadosísima y distinguida por Dios Padre, Santa María y todos los Santos, que murió el 21 de junio, año del Señor 1089». 
genosos homes, que oy equivale a Grande de España a lo menos de Segunda Clase; el término pisida confieso no haverle hallado, y sin duda a Piíssima.

En el paño de el claustro dond e está Nuestra Señora de las Aguas, se halla el siguiente epitafio:

Sancia Segunvit se totam Rex tibi Christe mete vivit corpus tumulus tegit iste obiit dona Sancia filia fabandi escacha, et visir Domini Sancii Benedicti, nonio maii anno domini milessimo duçentessimo octoagesimo secundo era millesima trecentesima vigesima.

En romance: Sancha, con firme resolución, siguió tus pisadas 1 o Rey Christo. Este túmulo guarda mi cuerpo que para ti vive. Doña Sancha, hija de Derbado Escacha, y mujer de don Sancho Benito tercero, murió en 7 de mayo del año del Señor 1282, era de 1320.

\section{Fol. 1v}

Nota: Aunque la tradución no es rigurosa, pero puede dar luz para su caval versión, la que yo no puedo dar por la causa del mete y tibi y tal vez dixa: meum. Adviértase que al principio dice Sancia, y después Dona Sancia, por ser ya muger de don Sancho, y Ferbado no tiene don, por lo que colige que Sancha era hija de algún caballero vascongado y casó con algún rey de Navarra o señor de Vizcaya. El don solamente lo han usado en España los cavalleros de primer orden hasta habrá tres siglos. A Hernán Cortés, por mucha grandeza, le concedió Carlos V que pudiese llamarse don Hernán Cortés por haver conquistado México. Se infiere que aunque Sancha y su padre Ferbado Escacha no fuesen príncipes o reyes, pudieron ser de la primera nobleza, quando casó con uno que sin duda fue rey, como consta de el título Sancho III, pues solo los reyes se llaman con nombre numerado.

\section{Documento 4.}

S. XVIII-S.XIX, Monasterio de Santa María de Vileña, Burgos.

Nota introductoria de carácter histórico presente en el Cartulario del monasterio, relativa al origen del mismo y al linaje y ascendencia de su fundadora.

A. AHN, Clero, Códices, L. 1168, f. 0 v. 
El padre de nuestra reyna ${ }^{170}$ se llamó don Lopez de Haro, señor de Bizcaya, y su mujer, Toda Pérez. Están sus cuerpos en el real monasterio de Náxera ${ }^{171}$. Si esta noticia debe corregirse porque la madre de la reina doña Urraca se llamó seguramente doña Aldonza Ruiz ${ }^{172}$, matrona insigne, que habiendo fundado santamente con el conde don Lope Díaz de Haro el monasterio de Cañas, y poco antes fundado o donado el monasterio de Santa María de Fayola, cerca de Santo Domingo de la Calzada, se trasladó o unió a Cañas, apenas murió el conde se hizo religiosa, en dicho convento de Cañas, en compañía de una hija, llamada también Urraca, que fue después abadesa allí, y muy célebre así por las obras que hizo en él, como por grande virtud. Esto lo trata el analista de la Orden, el señor Manri$q^{173} \mathrm{e}^{173}$ y produce las escrituras antiguas que hacen manifiesto lo que aquí se dice. Sin embargo, es posible que don Lope tuviese amas: y a doña Aldonza Ruyz, a doña Toda en primer matrimonio.

\footnotetext{
${ }^{170}$ Las monjas tenían un sentido de pertenencia a un linaje monástico fundado por la reina leonesa, cuyo estatus, adquirido por matrimonio, se emplea aquí para resaltar la importancia del monasterio en función de su aparición vinculada a una dama de la realeza, de mucho mayor peso que las fundaciones nobiliarias. ${ }^{171}$ El texto confunde a Diego López de Haro y su segunda esposa, Toda Pérez de Azagra, enterrados en el claustro de Santa María la Real de Nájera, monasterio al que realizaron importantes donaciones. SALAZAR Y CASTRO, L., Historia... Vol. 2, Libro XVI, p. 63.

${ }^{172}$ Segunda esposa de Lope Díaz I de Haro.

${ }^{173}$ Toma los datos de una fuente de autoridad, los Annales Cistercienses de Ángel Manrique (1577-1649), por lo que el escrito debe fecharse con posterioridad a la redacción de esta obra.
} 